\title{
THE ECOLOGY OF SOME PARASITIC COPEPODS OF GADOIDS AND OTHER FISHES
}

\author{
By N. G. Sproston and P. H. T. Hartley \\ From the Plymouth Laboratory
}

(Text-figs. I-2)

\begin{abstract}
CONTENTS

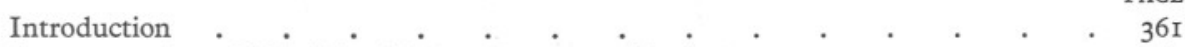

Lernaeocera branchialis (Linn.) (Fam. Lernaeoceridae) . . . . $\quad 362$

The relation between the migratory habits of Gadus merlangus and $\dot{G}$. pollachius and their infection with Lernaeocera branchialis . . . . . . . 362

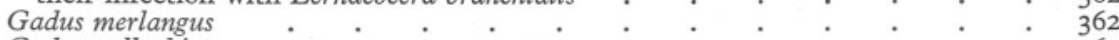

Gadus pollachius . . . . . . . . . . . 365

The relation between parasitism and the growth of the fish $\quad . \quad . \quad . \quad . \quad 367$

Discussion of the possible physiological factors influencing infected fish $: \quad . \quad 368$

The susceptibility of the different gadoids to infection with Lernaeocera spp. $\quad 37 \mathrm{I}$

The duration and distribution of the developmental phases of Lernaeocera branchialis 373

Multiple infections of Gadus merlangus and G. pollachius with L. branchialis . . 379

Clavella uncinata (O. F. Müller) (Fam. Lernaeopodidae) . . . . . . 380

Some factors influencing its distribution on Gadus merlangus and $\dot{G}$. pollachius $\quad 380$

The duration and distribution of the later developmental phases of Clavella uncinata 382

Multiple infections . . . . 384

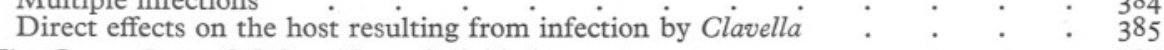

The Genus Lepeophtheirus (Fam. Caligidae) . . . . . . . . . $\quad . \quad 386$

Notes on the distribution of Lernaeenicus spp. on the Sprat _ . . . . . . $\quad 387$

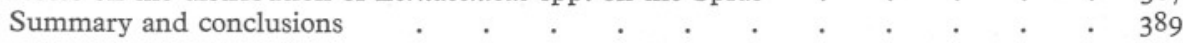

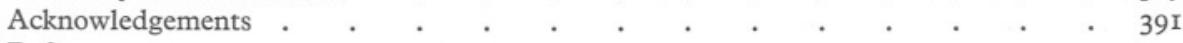

References . . . . . . . . . . . . . . . . $39 \mathrm{I}$
\end{abstract}

\section{INTRODUCTION}

During the study of the ecology of some fishes in the Tamar estuary in 1935-7 by one of us (Hartley, 1940), certain data concerning parasitic copepods of gadoids were collected, and as these were unpublished it was thought profitable to combine them with similar observations made during the period 1939-40 by the other author on gadoids caught in the sea nearby. The latter material was from two distinct habitats: (i) those fish caught in the trawl by the laboratory motor-boat Gammarus fishing within the limits of Plymouth Sound, together with those trawled by the Salpa in August 1939 from the Shagstone Grounds, which, although outside the Sound, are of similar depth (not more than 5 fathoms) and can be included with it under 'inshore waters'; (ii) other fish obtained from commercial trawlers fishing outside Tor Bay, Start Bay and over Rame Muds. The depth at which the latter were obtained is unknown, 
but probably all were from water between I0 and 30 fathoms in depth; these grounds are considered as 'offshore waters'.

An analysis of these combined data throws some light on the distribution, and the factors controlling it, of some of the commoner copepod parasites of gadoids.

\section{LERNAEOCERA BRANCHIALIS (LINN.) (FAM. LERNAEOCERIDAE)}

The Relation between the Migratory Habits of Gadus merlangus and

G. pollachius and their Infection with Lernaeocera branchialis

Length-frequency tables relating to Gadus merlangus, G. pollachius and G. luscus caught in the estuaries of the Tamar and the Lynher during 1936 and 1937 have already been published (Hartley, I940, pp. 47-5I). Though the numbers of fish were rather small, the results tend to show that these gadoids enter the estuaries when they are a few months old and remain there for some Io months, growing rapidly in the spring and early summer and less so in the autumn and winter. Throughout the estuarine period there seems to be a gradual leakage of the stock out to sea, but the main exodus usually takes place in the following spring.

Lernaeocera branchialis is a large blood-feeding parasite found projecting from the gill chamber of our more important food species of gadoids, Gadus morrhua, G. merlangus and G. pollachius, but only the last two are common at Plymouth. The irregular distribution of this parasite and its effect on the young stock seemed worthy of investigation. We had at our disposal records of superficial examinations of over a thousand specimens of the two commonest gadoids from the Tamar estuary which were caught in the tuck-net during 1936 and 1937, and more detailed dissections of 245 of the same species from the sea nearby caught in the trawl during 1939 and 1940.

The chief points brought out by these data are: (i) that the young fish migrating inshore are free from parasites and become infected after entering inshore or estuarine waters, and (ii) that infected fish tend to behave abnormally and do not return to the open sea with the main stock.

\section{Gadus merlangus}

This species was twice as common as Gadus pollachius and G. luscus in the Tamar estuary; G. pollachius was also infected with Lernaeocera branchialis in the Tamar, but length data of infected fish are only available for Gadus merlangus, and these are set out in Table I A, and in histogram form in Fig. I. The correlation between the migratory habits of this species and its infection with Lernaeocera branchialis in the Tamar estuary is indicated by the following summary of the facts illustrated in Fig. I.

Recruitment of the small fish of year-class 0 , with length range 4-Io cm., took place in May, but none of these young fish was infected. Though over 300 gadoids of less than $10 \mathrm{~cm}$. long have been examined, no fish less than II.0 $\mathrm{cm}$. 
TABLE I. INFECTION OF GADUS MERLANGUS WITH LERNAEOCERA BRANCHIALIS AND CLAVELLA UNCINATA

A. From the Tamar Estuary, 1936 and 1937 (P.H.T.H.)

\begin{tabular}{|c|c|c|c|c|c|c|c|}
\hline \multirow{3}{*}{$\begin{array}{c}\text { Month } \\
1936\end{array}$} & \multirow{2}{*}{$\begin{array}{l}\text { Total } \\
\text { fish } \\
\text { examined }\end{array}$} & \multirow{2}{*}{$\begin{array}{l}\text { No. } \\
\text { over } \\
\text { IO } \mathrm{cm} .\end{array}$} & \multirow{2}{*}{$\begin{array}{l}\text { A.M.L. } \\
\text { for } \\
\text { month }\end{array}$} & \multicolumn{2}{|c|}{ With Lernaeocera } & \multicolumn{2}{|c|}{ With Clavella } \\
\hline & & & & No. & A.M.L. & No. & A.M.L. \\
\hline & & & & & & & \\
\hline i & 4I & $4 \mathrm{I}$ & $20 \cdot 14$ & 9 & $20 \cdot 16$ & I & (19.7) \\
\hline ii & 48 & 48 & 20.68 & ó & & $\circ$ & \\
\hline iii & 16 & I6 & $19 \cdot 13$ & 8 & $20 \cdot 63$ & o & - \\
\hline iv & 4 & 4 & $20 \cdot 30$ & 4 & $20 \cdot 30$ & o & - \\
\hline $\mathrm{v}$ & 27 & 5 & $8 \cdot 0$ & o & - & 0 & - \\
\hline vi & 5 & 0 & $(6 \cdot 3)$ & 0 & - & 0 & - \\
\hline vii & 23 & 9 & 8.5 & 2 & $(19 \cdot 0)$ & o & - \\
\hline viii & 68 & 64 & 12.05 & 9 & I2.94 & 20 & I 2.35 \\
\hline ix & 12 & 12 & $14 \cdot 25$ & 3 & 14.5 & 2 & $(14.5)$ \\
\hline $\mathrm{x}$ & 9 & 9 & 15.85 & 6 & 17.5 & 2 & $(13.5)$ \\
\hline $\mathrm{xi}$ & 7 & 7 & 16.5 & 5 & I7.0 & I & $(14.5)$ \\
\hline xii & 4 & 4 & $16 \cdot 5$ & 3 & 16.8 & I & $(15.5)$ \\
\hline I937 & & & & & & & - \\
\hline $\mathrm{i}$ & 4 & 4 & 18.5 & $\begin{array}{l}4 \\
\text { I }\end{array}$ & $\begin{array}{l}18.5 \\
\text { (18.5) }\end{array}$ & $\begin{array}{l}\circ \\
\circ\end{array}$ & 二 \\
\hline ii & $\begin{array}{l}\text { I } \\
\text { I }\end{array}$ & $\begin{array}{l}\text { I } \\
\text { I }\end{array}$ & 18.5 & $\begin{array}{l}\text { I } \\
\text { I }\end{array}$ & $\begin{array}{l}(10.5) \\
(15.5)\end{array}$ & 0 & 二 \\
\hline iii & $\begin{array}{l}1 \\
0\end{array}$ & $\begin{array}{l}\text { I } \\
\text { O }\end{array}$ & 15.5 & & $(152)$ & 0 & 二 \\
\hline iv & $\begin{array}{l}\circ \\
\circ\end{array}$ & $\begin{array}{l}\circ \\
\circ\end{array}$ & - & $\begin{array}{l}\circ \\
0\end{array}$ & 二 & 0 & 二 \\
\hline $\mathrm{v}$ & $\begin{array}{r}0 \\
189\end{array}$ & $\begin{array}{r}0 \\
37\end{array}$ & $\overline{8 \cdot 34}$ & I & $(\mathrm{II} \cdot 5)$ & 0 & 二 \\
\hline $\begin{array}{l}\text { vi } \\
\text { vii }\end{array}$ & $\begin{array}{r}189 \\
65\end{array}$ & $\begin{array}{l}37 \\
58\end{array}$ & $\begin{array}{r}8.34 \\
12.0\end{array}$ & 3 & 14.5 & 0 & 二 \\
\hline $\begin{array}{l}\text { vii } \\
\text { viii }\end{array}$ & $\begin{array}{l}05 \\
66\end{array}$ & 66 & 14.4 & $\mathrm{I}$ & & & 二 \\
\hline$\underset{\text { viii }}{\text { vix }}$ & 49 & 49 & $\begin{array}{l}4.4 \\
\text { I } 5.8\end{array}$ & 5 & $\begin{array}{l}15.3 \\
16 \cdot 1\end{array}$ & I & $(\overline{5 \cdot 5})$ \\
\hline ix & $\begin{array}{l}49 \\
10\end{array}$ & $\begin{array}{l}49 \\
\text { I0 }\end{array}$ & $\begin{array}{l}13.0 \\
18.6\end{array}$ & I & $(19.6)$ & I & $\begin{array}{l}15.5) \\
(14.5)\end{array}$ \\
\hline $\mathrm{x}$ & 55 & 55 & $\begin{array}{l}180 \\
18.9\end{array}$ & Io & I $8.6 \mathrm{I}$ & 3 & 17.5 \\
\hline $\begin{array}{l}\text { xi } \\
\text { xii }\end{array}$ & $\begin{array}{l}55 \\
\text { II }\end{array}$ & II & $16 \cdot 2$ & I & (I6.5) & I & $\begin{array}{l}17.5 \\
\text { (I4.5) }\end{array}$ \\
\hline Total & 715 & $5 \mathrm{II}$ & & 77 & & 33 & \\
\hline
\end{tabular}

B. From Inshore and Offshore Waters near Plymouth, 1939 and I940 (N.G.S.)

\begin{tabular}{|c|c|c|c|c|c|c|c|c|}
\hline \multirow[b]{2}{*}{ Month } & \multirow[b]{2}{*}{ Origin } & \multirow{2}{*}{$\begin{array}{c}\text { Total } \\
\text { fish } \\
\text { examined }\end{array}$} & \multirow{2}{*}{$\begin{array}{l}\text { No. } \\
\text { over } \\
\text { IO } \mathrm{cm} .\end{array}$} & \multirow{2}{*}{$\begin{array}{l}\text { A.M.L. } \\
\text { for } \\
\text { month }\end{array}$} & \multicolumn{2}{|c|}{ With Lernaeocera } & \multicolumn{2}{|c|}{ With Clavella } \\
\hline & & & & & No. & A.M.L. & No. & A.M.L. \\
\hline $\begin{array}{c}\text { I939 } \\
\text { viii }\end{array}$ & Sh. & 24 & 24 & 29.5 & 6 & 30.0 & 5 & $29 \cdot 8$ \\
\hline $\mathrm{x}$ & R. & 7 & 7 & 30.0 & o & - & I & 27.5 \\
\hline $\mathrm{xi}$ & R. & 4 & 4 & 27.5 & $\circ$ & - & $\circ$ & \\
\hline $\mathrm{xi}$ & P. & 2 & 2 & $(15.0)$ & $\circ$ & - & 2 & $(15.0)$ \\
\hline I940 & & & & & & & & \\
\hline $\mathrm{v}$ & P. & 4 & 4 & 15.0 & 3 & I4.7 & 2 & 15.6 \\
\hline vii & T. & $3 I$ & $3 \mathrm{I}$ & 23.8 & 2 & 24.0 & 2 & $\begin{array}{r}22.9 \\
\end{array}$ \\
\hline vii & P. & 4 & 2 & $8 \cdot 6$ & $\circ$ & - & I & $(\mathrm{II} \cdot 7)$ \\
\hline viii & $\mathrm{R}$. & $\begin{array}{r}4 \\
14\end{array}$ & I4 & 24.0 & o & - & 4 & 24.0 \\
\hline ix & P. & I & I & $(\mathrm{II} \cdot 0)$ & I & $(\mathrm{II} \cdot \mathrm{O})$ & I & $(\mathrm{II} \cdot 0)$ \\
\hline $\mathrm{x}$ & R. & 9 & 9 & 24.9 & 0 & - & 0 & - \\
\hline $\mathrm{x}$ & St. & 4 & 4 & $24 \cdot 2$ & 0 & - & 0 & - \\
\hline $\mathrm{xi}$ & $\mathrm{R}$. & 4 & 4 & $24 \cdot 8$ & 0 & - & I & $(23 \cdot 5)$ \\
\hline Tota & & 108 & 106 & & I 2 & & I9 & \\
\hline
\end{tabular}

Note. A.M.L. = arithmetic mean length; P.=Plymouth Sound; R.= Rame Muds area; Sh. = Shagstone Grounds; St. = Start Bay; T.= Tor Bay. 
was found infected (i.e. after 2-3 months of estuarine life). A length of $10 \mathrm{~cm}$. has thus been taken as the arbitrary minimum, and only fish larger than this are included in the following analyses.

May to August was the period of rapid growth during which time the stock became infected. Infection did not necessarily take place at the same time for all fish, though information as to the state of maturity of the parasites relative to the length of the host is lacking for the Tamar material. In August 1936, 9 out of 64 of the rapidly growing new stock were infected, or $13.1 \%$ (for the LENGTH OF FISH IN CM.

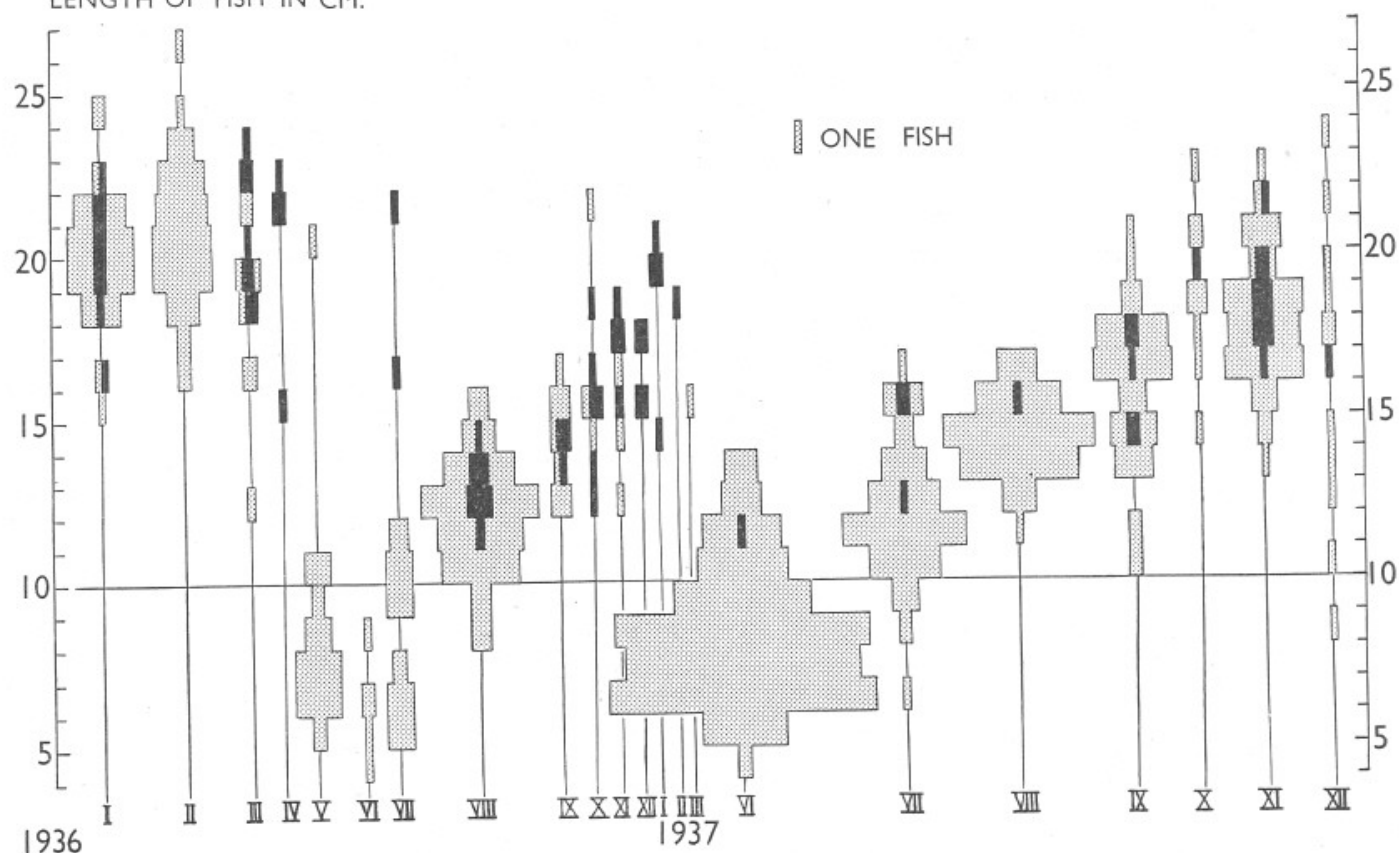

Fig. I. Histogram representing the total fish examined from the Tamar estuary in I 936 and I937. Infected fish shown black and uninfected fish stippled. Ordinates represent the length of the fish in $\mathrm{cm}$. and the numerals along the abscissae indicate months.

whole period of rapid growth the infection was 9 out of 75 or 12.0\%). For the same period in 1937 only 5 out of I6I fish were infected, or $3 . \mathrm{I} \%$. A period of less rapid growth followed, normally from September to the following spring, and ended in the run to sea; but in September 1936 though netting continued as before, there was a marked fall in the numbers of whiting caught. This may indicate a precocious run to sea of fish mostly less than $15 \mathrm{~cm}$. in length. From September to December 1937 the slowly growing stock showed a four-fold increase in infection-17 out of 125 , or $13.6 \%$. The 1935 stock persisted into the spring of 1936 , and a similar persistence of the 1937 stock is hinted at, in spite of the irregularity in the numbers of fish caught towards 
the end of the year. Apart from the anomalous absence of infection in February 1936, the rate of infection over the first 3 months of 1936 was fairly high, I7 out of the I05 fish, or $16.2 \%$, which is of the same order as that obtained for the period of slow growth at the end of 1937 .

Factors governing the run to sea are unknown, but it does not seem to be dependent on the attainment of a certain minimum size or on the availability of food (cf. the precocious run to sea of small fish in midsummer of 1936); however, at some time after the period of rapid growth there is a sudden fall in the numbers of fish caught: the 1935 stock fell $76 \%$ in March I936, and the 1936 stock fell $82 \%$ in September of the same year. It was immediately after this exodus that the remaining fish showed a sudden increase in the rate of infection which had a tendency to approach roo \%. These large infected fish lingered in the estuary for some months after the arrival of the new stock.

A comparatively few Gadus merlangus were examined from inshore waters (Table I B and Fig. 2b), but about half of the small fish (year classes $\mathrm{O}$ and i) were infected, and they are evidently a counterpart of the lingering postexodus fish of the Tamar which had failed to reach the sea with the main stock. In spite of the small number of fish examined from offshore waters, their freedom from infection with Lernaeocera is remarkable: in Fig. $2 c$ the two infected specimens came from a haul 'off Tor Bay' and may possibly have been taken in the shallower waters of the bay itself. It may be concluded, therefore, that the year class i whiting leaving the rivers and making out to sea in the normal way are very rarely parasitized by Lernaeocera, nor do they become infected after reaching the deeper waters.

\section{Gadus pollachius}

This species was only a third as common as G. merlangus in the estuary but about three times as frequently met with as the latter species in Plymouth Sound (Table II). A similar length distribution throughout the year was found in the Tamar for pollack as for whiting, but the growing fish showed less regularity in numbers (Hartley, I940, Table VIII). An outstanding difference is the later date-in June-at which recruitment took place, which is explained by breeding starting some weeks later than that of the whiting. The length distribution of inshore pollack (Fig. 2a) shows what at first sight appears to be a bimodal curve, but this may be due to the irregular breeding of this species, which in some years breeds so late that young only appear inshore in the winter. This must have been so in 1939 to account for the double banking of the histograms for 1940. It is a remarkable fact that, at Plymouth, small bronze coloured pollack were taken at all times, except during midsummer, in the Sound; these fish appeared to be in good condition, and the examination of their stomach contents showed that their diet consisted mainly of crustaceans, but that in the autumn and winter small teleosts had been eaten, also Mollusca and vegetable matter such as Enteromorpha and Zostera. In the spring, IO-I $5 \mathrm{~cm}$. fish usually contained polychaete remains; 


\section{TABLE II. INFECTION OF GADUS POLLACHIUS}

A. From the Tamar Estuary, 1936 and 1937 (P.H.T.H.)

$\begin{array}{cccc}\begin{array}{c}\text { Month } \\ \text { i }\end{array} & \begin{array}{c}\text { Total fish } \\ \text { examined }\end{array} & \begin{array}{c}\text { No. over } \\ \text { Io cm. }\end{array} & \begin{array}{c}\text { No. with } \\ \text { Lernaeocera }\end{array} \\ \text { ii } & \text { I3 } & \text { I3 } & 2 \\ \text { iii } & \text { I9 } & \text { I9 } & 0 \\ \text { iv } & 8 & 8 & \text { I } \\ \text { v } & \text { I } & \text { I } & \text { - } \\ \text { vi } & \text { I30 } & 0 & - \\ \text { vii } & 48 & 0 & 0 \\ \text { viii } & \text { I8 } & 48 & \text { I8 } \\ \text { ix } & 4 & 4 & 0 \\ \text { x } & \text { I0 } & \text { I0 } & 3 \\ \text { xi } & \text { I9 } & \text { I9 } & 4 \\ \text { xii } & \text { I7 } & \text { I7 } & \text { I } \\ \text { Total } & 287 & \text { I57 } & \text { II }\end{array}$

B. From Inshore and Offshore Waters near Plymouth, 1939 and 1940 (N.G.S.)

\begin{tabular}{|c|c|c|c|c|c|c|c|c|c|c|}
\hline \multirow[b]{2}{*}{ Month } & \multirow[b]{2}{*}{ Origin } & \multirow{2}{*}{$\begin{array}{l}\text { Total } \\
\text { fish ex- } \\
\text { amined }\end{array}$} & \multirow{2}{*}{$\begin{array}{l}\text { No. } \\
\text { over } \\
\text { IO cm. }\end{array}$} & \multirow{2}{*}{$\begin{array}{l}\text { A.M.L. } \\
\text { for } \\
\text { month }\end{array}$} & \multicolumn{2}{|c|}{$\begin{array}{c}\text { With } \\
\text { Lernaeocera }\end{array}$} & \multicolumn{2}{|c|}{$\begin{array}{l}\text { With } \\
\text { Clavella }\end{array}$} & \multicolumn{2}{|c|}{$\begin{array}{c}\text { With } \\
\text { Lepeophtheirus }\end{array}$} \\
\hline & & & & & No. & A.M.L: & No. & A.M.L. & No. & A.M.L. \\
\hline $\begin{array}{c}\text { I939 } \\
\text { viii }\end{array}$ & St. & I & I & $(38.5)$ & 0 & - & 0 & - & & - \\
\hline ix & P. & I & 0 & - & - & - & - & - & 0 & - \\
\hline $\mathrm{x}$ & R. & 4 & 4 & $28 \cdot 25$ & 0 & - & 2 & $(30 \cdot 0)$ & 2 & $(28.0)$ \\
\hline xi & P. & 2 & 2 & 16.0 & o & - & I & $(17.5)$ & 0 & - \\
\hline xii & P. & 3 & 3 & $12 \cdot 66$ & I & $(12 \cdot 0)$ & 0 & - & o & - \\
\hline \multicolumn{11}{|l|}{ I940 } \\
\hline i & P. & 3 & 3 & II 58 & 0 & - & I & $(\mathrm{II} \cdot 5)$ & 0 & - \\
\hline i & P. & I & I & $25 \cdot 5$ & 0 & - & I & $(25 \cdot 5)$ & I & $(25 \cdot 5)$ \\
\hline ii & P. & 4 & 4 & $\mathrm{I} 2 \cdot \mathrm{I} 4$ & 0 & - & 2 & (12.4) & 0 & - \\
\hline iii & P. & 2 & 2 & $13.7^{\circ}$ & 0 & - & 0 & - & 0 & - \\
\hline iv & P. & I3 & I3 & 13.6 & 4 & $\mathrm{I} 4 \cdot 3$ & 2 & (I4.3) & I & (I4.0) \\
\hline iv & P. & I & I & $22 \cdot 5$ & I & $(22 \cdot 5)$ & I & $(22 \cdot 5)$ & I & $(22 \cdot 5)$ \\
\hline $\mathrm{v}$ & P. & IO & IO & 14.5 & 3 & I4. 5 & 3 & I 4.7 & 0 & - \\
\hline $\mathrm{v}$ & P. & I & I & $2 \mathrm{I} \cdot 0$ & 0 & - & 0 & - & 0 & - \\
\hline vi & P. & 4 & 3 & 16.6 & 2 & 17.0 & 2 & $17 \cdot 0$ & 0 & - \\
\hline vii & P. & I4 & 3 & 15.4 & 2 & I6.9 & I & $17 \cdot 7$ & I & (I7.7) \\
\hline viii & P. & 43 & 29 & I I 4 & 4 & I6. I & 3 & I3.5 & 0 & - \\
\hline ix & P. & 6 & 6 & 12.55 & o & - & 4 & 13.3 & 0 & - \\
\hline$x$ & P. & 3 & 3 & 13.0 & 2 & 12.75 & I & 13.3 & 0 & - \\
\hline xi & P. & 20 & 20 & I3. 8 & I & $($ I 5.8$)$ & 8 & I 4.4 & 0 & - \\
\hline xi & P. & I & I & $2 \mathrm{I} \cdot 0$ & I & $(2 \mathrm{I} \cdot 0)$ & I & $(2 \mathrm{I} \cdot 0)$ & I & $(2 \mathrm{I} \cdot \mathrm{O})$ \\
\hline Total & & I 37 & I IO & & $2 \mathrm{I}$ & & 33 & & 7 & \\
\hline
\end{tabular}

A.M.L. $=$ arithmetic mean length; P. = Plymouth Sound; R. = Rame Muds area; St. $=$ Start Bay.

C. Fish Infected with Lepeophtheirus pollachii. Inshore Waters, 1939 and 1940 (N.G.S.)

$\begin{array}{lcccc}\text { Length range } & \begin{array}{c}\text { No. fish } \\ \text { examined }\end{array} & \text { No. } & \text { A.M.L. } & \% \\ \text { IO-I5 cm. } & 87 & \text { I } & (14 \cdot 0) & 1 \cdot 15 \\ \text { Over } 15 \mathrm{~cm} . & 25 & 4 & 19 \cdot 2 & 16 \cdot 0\end{array}$

Offshore fishes, 1939 and I940 (N.G.S.)

Over $15 \mathrm{~cm}$.

Total fish over $15 \mathrm{~cm}$. All pollack

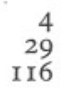

2
6
7

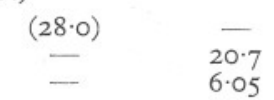


it was extremely rare to find a stomach empty. The lingering of pollack infected with Lernaeocera branchialis is better demonstrated from our records of inshore fish than from those from the estuary. Estuarine fish showed a rate of infection for the two years of only $7 \%$ (Tables II A and III A): Io of these II infected fish were taken after the period of rapid growth (September-March I936-7), when the whiting from the same area showed a remarkably high degree of infection $(59 \%)$, the infection rate for pollack for the latter period alone being $16 \%$.

Only four large fish (year class ii) were brought in from over the Rame Muds, but none of these was infected (Fig. $2 a$, 'offshore'). Pollack, there-
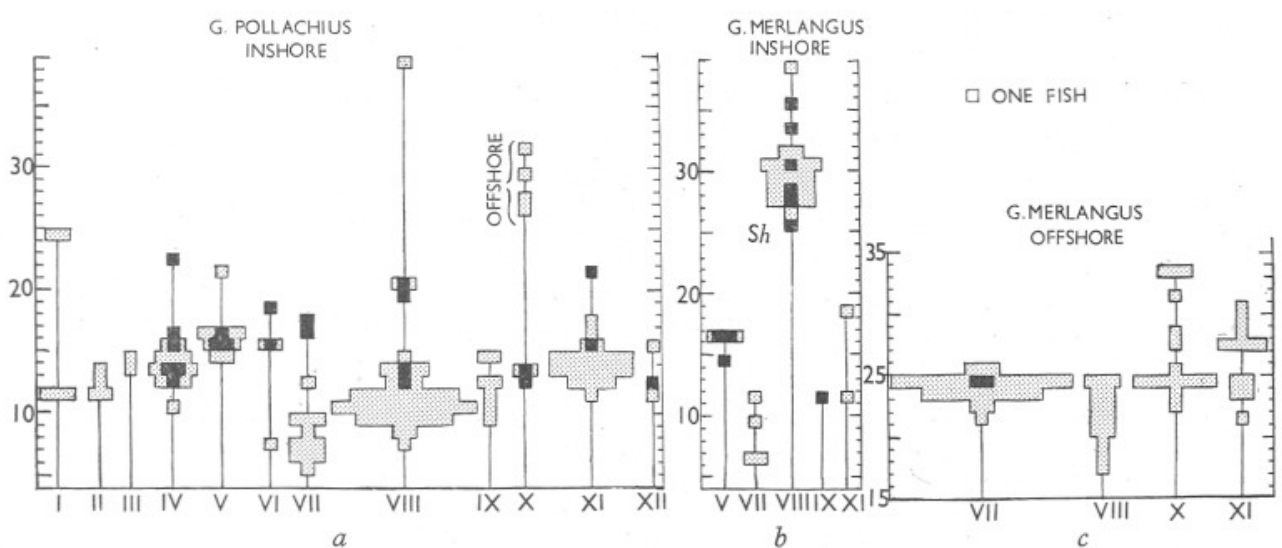

Fig. 2. Histograms representing the total numbers of fish examined from inshore and offshore waters near Plymouth during 1939 and I940. Infected fish are shown black and uninfected fish stippled. Ordinates represent the length of the fish in centimetres (to the nearest half $\mathrm{cm}$. above) and the numerals along the abscissae indicate months. Sh, fish caught from Shagstone Grounds, 1939.

fore, like whiting, become infected during their inshore or estuarine phase, more particularly in the former habitat, according to our observations.

\section{The Relation between Parasitism and the Growth of the Fish}

The causal trend of the correlation discussed above would seem to be that parasitism with Lernaeocera branchialis has some physiological effect on these gadoids which delays their seaward migration, rather than the fish remaining behind through some other set of circumstances and becoming parasitized owing to longer exposure to infection. The latter possibility can be tested by reference to Table III, in which the rates of infection for both species of fish are summarized according to their length groups for the three habitats. Owing to a significant number of Gadus merlangus being caught in the Tamar (A), the figures for this habitat are separated into the period of rapid growth (May-August) and the rest of the year when growth is slower (SeptemberApril). During the latter period the degree of infection is very nearly the same for both size groups, notwithstanding the small number of young fish, 
whereas of the 226 larger fish only 53 were infected. If infection were a simple function of the size of the fish, i.e. depending mainly on the volume of potentially infective water passing over the gills, and on the length of time the fish remained exposed to infection, then the larger fish would be expected to show a much higher percentage infection than the smaller, whereas this was not so. That the larger fish show three times the infection of the smaller in the first period is, however, explained by referring to Fig. I which shows that they are represented by the lingering of the old stock which is very heavily infected; this same fact is reflected in the annual rates shown in the last column of Table III A.

In G. merlangus from inshore waters the $31 \%$ total infection is very high, but it is made up as already suggested by small fish lingering behind the main stock on their way to sea from the rivers. The group of larger fish (probably in their third year), shown above $S h$ in Fig. $2 b$, were caught on Shagstone Grounds in the squid trawl in no more than 5 fathoms of water, so they may be included in the inshore habitat: incidentally, they show about the same rate of infection as the larger fish from estuarine waters.

G. pollachius from inshore waters show five times the infection in older fish than in younger fish, when figures for the whole period are taken (Table III B): no seasonal separation is justifiable owing to the irregularity in length distribution and the small samples available. That this marked difference is due to the 'lingering' phenomenon is evident from Fig. $2 a$.

\section{Discussion of the possible Physiological Factors influencing Infected Fish}

The nature of the physiological changes in these two species of gadoids effected by the presence of Lernaeocera branchialis, and having their main outcome in the postponement of the run to sea, is unknown. There are several lines of approach to the problem of the direct effect of this parasite on its host, and some of these may be considered here. The condition of parasitized fish as compared with non-parasitized has been examined during the 1939-40 investigations; the condition factor $K=\frac{w \times 100}{l^{3}}$ (where $w$ is the weight of the fish in grams and $l$ is the length in centimetres) has been used. These figures for each fish are not reproduced here, for it was found that they showed no correlation whatever with infection. The value of $K$ is considered unreliable when individual differences are sought among fish at very different growth stages. The greatest error, perhaps, is introduced by the gross weight of the fish which includes the highly variable stomach contents. Though there are no records published of any measurement of the condition of fish infected with this parasite, Andrew Scott (1929, pp. 106-8) states that during the heavy infection year of 1928 the young whiting from the shrimping grounds between Mersey and Dee showed so marked an emaciation that infected ones could be picked out at a glance. Thomas Scott (1909, p. 90) makes the statement that 'whitings and other gadoids have been captured reduced almost to 
skin and bone, having one or more large worm-like Lernaea [=Lernaeocera] hanging at their gills full of the red blood they had extracted therefrom'. Such emaciation has never been observed by us.

\section{TABLE III. INFECTION OF GADUS MERLANGUS AND G. POLLACHIUS WITH LERNAEOCERA BRANCHIALIS SUMMARIZED ACCORDING TO THE GROWTH OF THE FISH}

A. From the Tamar Estuary, 1937 and 1937 (P.H.T.H.)

\begin{tabular}{|c|c|c|c|c|c|c|c|c|c|}
\hline \multirow{4}{*}{$\begin{array}{l}\text { Length } \\
\text { range }\end{array}$} & \multicolumn{6}{|c|}{ Gadus merlangus } & & & \\
\hline & \multicolumn{3}{|c|}{ May to August } & \multicolumn{3}{|c|}{ September to April } & \multicolumn{3}{|c|}{ All months } \\
\hline & \multirow{2}{*}{$\begin{array}{l}\text { No. } \\
\text { fish ex- } \\
\text { amined }\end{array}$} & \multicolumn{2}{|c|}{ Infected fish } & \multirow{2}{*}{$\begin{array}{l}\text { No. } \\
\text { fish ex- } \\
\text { amined }\end{array}$} & \multicolumn{2}{|c|}{ Infected fish } & \multirow{2}{*}{$\begin{array}{l}\text { No. } \\
\text { fish ex- } \\
\text { amined }\end{array}$} & \multicolumn{2}{|c|}{ Infected fish } \\
\hline & & No. & $\%$ & & No. & $\%$ & & No. & $\%$ \\
\hline $\begin{array}{l}\text { IO-I } 5 \mathrm{~cm} \text {. } \\
\text { I5-25 cm. }\end{array}$ & $\begin{array}{r}216 \\
32\end{array}$ & $\begin{array}{r}\text { II } \\
5\end{array}$ & $\begin{array}{r}5.1 \\
15.6\end{array}$ & $\begin{array}{r}37 \\
226\end{array}$ & $\begin{array}{r}8 \\
53\end{array}$ & $\begin{array}{l}2 I \cdot 6 \\
23 \cdot 2\end{array}$ & $\begin{array}{l}253 \\
258\end{array}$ & $\begin{array}{l}\text { I9 } \\
58\end{array}$ & $\begin{array}{r}7 \cdot 5 \\
22 \cdot 3\end{array}$ \\
\hline Total catches & 248 & 16 & $6 \cdot 45$ & 263 & $6 I$ & 23.5 & 5 II & 77 & I 5.0 \\
\hline
\end{tabular}

No length data of infected fish from Tamar available.

No infection recorded during the period May-August; October-April: of the 82 fish examined above ro cm., I I were infected (13.4\%).

Infection over the two-year period $=7 \%$.

B. From Inshore Waters, 1939 and $\mathrm{I} 940$ (N.G.S.)

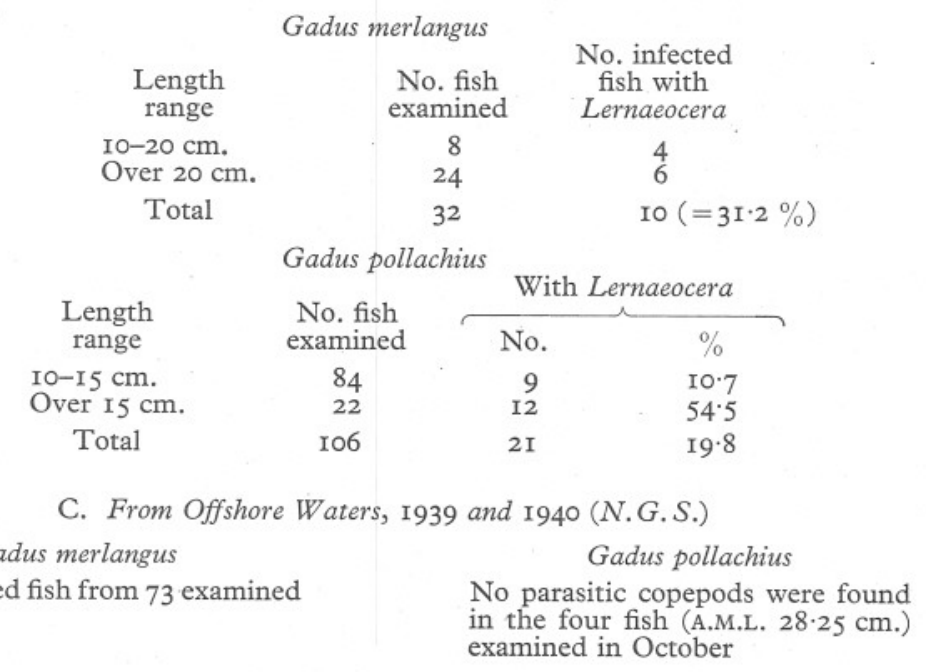

Had there been a retarding effect on the growth of the fish by the presence of the parasite it would have been evident in our records. In Tables I and II the arithmetic mean lengths of the monthly catch are given for comparison with the A.M.L. of the infected fish, and the unexpected correlation is found that, on the whole, the infected fish are larger than the uninfected, even when 
fish of the same size group are considered together, as they are for inshore and offshore fish. It is difficult to account for this anomaly, though two possibilities suggest themselves: first, that mere size is a favourable factor, a larger fish presenting a greater infective surface. Though this possibility was rejected above as an explanation of the higher rate of infection of large fish as a whole, it may possibly be operative here when a group of fish of a restricted length range, whether large or small, is being considered. The second possibility is that the smaller infected fish of each length group have been eliminated from the samples. Owing to the loss of blood (see below) and consequent reduction in respiratory efficiency, the weaker fish (i.e. those under the A.M.L. of the length group) may perhaps enter the surface water where the oxygen tension is higher; if so, they would not be caught in the trawl or in the tuck-net which operate over the bottom. Indeed they may, in these higher levels, become an easy prey for gulls and other predators.

Since infection has no measurable effect on these two species of gadoids at Plymouth, it would appear that they have, to a large extent, become tolerant of the parasite.

We have calculated that the capacity of the intestine of a fully grown Lernaeocera is at least roo c. mm., which is considerable in relation to the blood volume of a young gadoid. It is not known at what rate the parasite feeds, i.e. how often this volume is extracted from the host, though it is shown elsewhere that feeding is not a continuous process (Sproston \& Hartley, I94I). Granting, then, that the blood loss to Lernaeocera is probably far greater than that to any other parasite (that is, relatively and absolutely great), it would be of great interest to know the blood-cell counts of infected and uninfected fish; for in this way it might be possible to measure the effects of parasitism. Some degree of 'secondary anaemia' 1 is to be expected, for the loss of blood to the parasite would be made good by absorption of tissue fluids, via the capillary walls in the first instance, and finally equilibrated by absorption of water from the external medium (see below); the net result being a dilution of the tissue elements of the blood, and, perhaps, a greater or less strain on the haemapoietic organs. The various well-known symptoms of anaemia would contribute to a chronic cachexia which may well account for the parasitized fish failing to respond to the normal urge to run to sea.

A second possibility is tentatively suggested to account for the lingering of parasitized gadoids in estuarine and inshore waters: this concerns the osmoregulatory mechanism of the fish. The absorption of fluid from the external medium to make good the loss to the parasite is complicated by the fact that the gadoid is living in hypertonic media, whether it is in the sea or in estuarine waters. The salinities at various points in the estuaries of the Tamar and Lynher were determined by Milne (1938) who worked concurrently with one of us (P.H.T.H.) during the work on the Saltash tuck-net fishery there. It is

1 'Secondary anaemia' is used here in the clinical sense, to indicate the result of simple blood loss, in contrast to 'primary anaemia' which is defective blood-cell production. 
notoriously difficult to determine the exact salinity level at which fish are living in an estuary, but in all probability these gadoids normally remain near the bottom where changes in salinity are not so great as elsewhere. Though these fish were taken in the upper reaches of both estuaries in summer, in winter they were only caught in the neighbourhood of Saltash Bridge where the salinity did not fall below $25-24 \%$; this represents the minimum bottom salinity recorded, and probably a similarly low figure would be obtained from certain places in Plymouth Sound (Barn Pool, for instance, where a large proportion of our gadoids were obtained during the latter series of observations). The large 'lingering' infected gadoids found in the seaward end of the estuaries in autumn and winter when the rivers are in flood are therefore inhabiting media of a much lower salinity than the normal fish of the same size which have migrated to offshore habitats.

It is well known that the blood of marine teleosts has an osmotic concentration of only about a third of that of sea water. From the work of Smith (I930) and Keys (I933) it is now clear that the mechanism of regulation consists of drinking sea water and excreting the excess of salt through the gills. Excretion of salt against an osmotic gradient necessarily involves the expenditure of considerable energy. To quote from Smith's review of the subject (I932, p. II): 'a large fraction of the ingested and absorbed sea water is excreted extra-renally...nearly all the water excreted as urine must be procured from the sea water at the expense of considerable osmotic work.... Consequently the normal fish tends to keep the urine flow and the ingestion of sea water down to a minimum for the sake of physiological economy.' The choice of habitat may therefore be a physiological response to the necessity of absorbing additional sea water to maintain the normal blood volume (i.e. pressure equilibrium), and it is possible that to reduce the concomitant osmotic work the parasitized fish would tend to remain in media having the minimum salinity compatible with life.

It was hoped that these two hypotheses concerning the exact nature of the physiological upset of parasitized fish could have been tested experimentally; but so far it has been found to be impossible to keep the fish infected with Lernaeocera alive in the laboratory. This, in itself, is a pertinent fact. When batches of gadoids were brought into the aquarium only a few of the uninfected fish died in transit, but nearly always the infected fish would be found dead, floating venter upwards, with the operculum widely distended and the mouth open to the fullest extent; any surviving infected fish always died within an hour or so of being placed in the tanks. This, in fact, is the only direct effect of physiological upset observed by us in infected fish.

\section{The Susceptibility of the different Gadoids to Infection with Lernaeocera spp.}

From Table III it would appear that Gadus merlangus was twice as susceptible to infection with this parasite as G. pollachius in the estuaries, and that the susceptibility was $3: 2$ in inshore waters. When, however, our total 
figures for all habitats are taken together there is little difference between them:

\begin{tabular}{lccc}
\multicolumn{1}{c}{ Species } & $\begin{array}{c}\text { Total no. of } \\
\text { fish examined }\end{array}$ & $\begin{array}{c}\text { Total no. of } \\
\text { fish infected }\end{array}$ & $\%$ infection \\
G. merlangus & 616 & 89 & 14.5 \\
G. pollachius & 267 & 32 & 12.0 \\
Both species & 883 & I2I & 13.7
\end{tabular}

G. minutus migrates inshore during its first year, though from the data (Hartley, I940, p. 50) it does not appear to ascend the estuaries with any regularity. Of the 27 specimens examined from the Tamar and the Lynher during 1936 and 1937, none was infected with copepods. During 1939 and I940, I20 specimens were examined from the sea and were free from copepods with the exception of two fish, both well above the average size of our samples; one of them had a mature specimen of Lernaeocera branchialis attached to the anterior angle of the fourth gill arch. This is the first record of an adult of this species being found on Gadus minutus. Hesse (1870, and I89I, p. I9I, as quoted by Wilson, I9I7, p. 40) records what is considered to be a larval form on the gills of the same host. The occurrence of the parasite on this host seems to be rare, for G. minutus is quite as common as $G$. pollachius in inshore waters, and Ford (I93I) considers it to be the commonest gadoid on the local trawling grounds outside Plymouth Sound; yet the previous investigators of parasitic copepods at Plymouth who must have examined large numbers of this fish have never recorded the presence of Lernaeocera branchialis on it.

Gadus luscus is infrequent inshore, but of the eleven specimens from Rame Muds, three were infected with Lernaeocera lusci. During the previous investigations (1936, 1937) 289 fish of this species were examined from the Tamar, of which 246 were over Io $\mathrm{cm}$. in length; but only two of these were infected with Lernaeocera, which, in all probability was L. lusci, though they were not identified at the time. This parasite is specifically distinct from L. branchialis (a parasite rarely found on Gadus luscus): apart from certain morphological characters it differs from the latter species in its position of attachment to the host, being found attached to the gill arches at about the middle of their length and penetrating only into the branchial vessels. The host reaction is also different to this species: at the 'neck' of the parasite the branchial mucosa of the host is hypertrophied: a traumatic overgrowth in the form of a swollen collar which obscures much of the body of the parasite. This has also been observed by Vanden Berghe (I933), but is not mentioned by any other observer. It is common to find multiple infections of this species; one of the fish from Rame Muds had six Lernaeocera lusci. Since so low an infection rate (0.8I \%) was found for Gadus luscus in the Tamar, and a comparatively high one $(25 \%$ ) for the offshore fish it would seem that for this species infection takes place after the run to sea. It is possible, therefore, that the intermediate host carrying the copepodid stages and the males is different from that of Lernaeocera branchialis (Pleuronectes flesus), which is an active vector mainly in estuarine and inshore waters; so that the whole life cycle of 
L. lusci would seem to be passed in deeper offshore waters, a marked contrast to that of L. branchialis (see below). Scott \& Scott (I9I3, p. I45) record L. lusci from Gadus luscus caught ro miles off Aberdeen in January I90I.

Gadus morrhua is infrequent in the Tamar estuary, and only two out of the 20 fish examined from this habitat were infected with Lernaeocera branchialis; no fish of this species have been examined by us from the sea at Plymouth. A. Scott (1929, p. I08) says that the cod caught with the highly infected whiting were rarely infected off the Lancashire coast.

No Lernaeocera spp. were found by us on other gadoids: a few each of Gadus virens and Urophycis blennoides were examined from offshore, also 23 Onos mustela and a few each of O. tricirratus and O. maculata from inshore waters. Numbers of Callionymus lyra were examined from the estuary in 1936 and 1937, and some from inshore in 1939 and 1940, but they were free from copepod parasites.

\section{The Duration and Distribution of the Developmental Phases of Lernaeocera branchialis}

The life history of this parasite is well known, though the records of the developmental forms are not numerous in the literature. There is a freeswimming copepodid stage which becomes attached to the gill filaments of the flounder; here a series of modified copepodid stages are passed, finally giving rise to pelagic forms (redescribed by Sproston, I94I). The female is still cyclopoid in appearance but has an elongating genital segment; the male is similar to the infective copepodid. These pelagic forms remain within the gill cavity of the flounder for a short time, attachment being effected by the chelate second antennae; copulation takes place here and the male soon dies. The fertilized female leads a pelagic existence until it finds itself within the gill chamber of a gadoid; it then becomes attached near the anterior angle of the fourth gill arch and undergoes a peculiar metamorphosis. The long genital segment first twists and then dilates, and the cuticle becomes thicker. Meanwhile anchoring processes grow out from the sides and top of the cephalothorax, these becoming the bifurcating 'antlers' of the adult. Penetration continues, at first through the branchial vessels and then into the ventral aorta and often into the auricles. Occasionally fibrous and fatty tumours develop, but usually the only histological response is a fibrotic thickening of the vascular system around the anchoring structures. The suctorial form of mouth is situated on the end of a conical proboscis embedded in the blood vessel. The swollen genital segment becomes a darker red as the bloodfeeding habit continues. Two very long thin egg strings are extruded just above the small cylindrical abdomen; they are tightly coiled in a boss-like tangle and can often be seen projecting with the abdomen and part of the genital segment from the operculum of an infected gadoid. Owing to the permanent mode of attachment, the 'antlers' remain in situ after the death and fragmentation of the rest of the parasite. 
During the investigations by the first author (1939-40) data were collected with a view to determining the longevity of Lernaeocera and the age of the host when infection occurs. The development of the adult female on the gadoid has been separated, somewhat arbitrarily, into seven substages as

\section{TABLE IV. SUBSTAGES OF LERNAEOCERA BRANCHIALIS ON GADUS MERLANGUS AND G. POLLACHIUS}

From Inshore and Offshore Waters near Plymouth, I939 and I940 (N. G. S.)

A. Distribution of Substages Throughout the Year

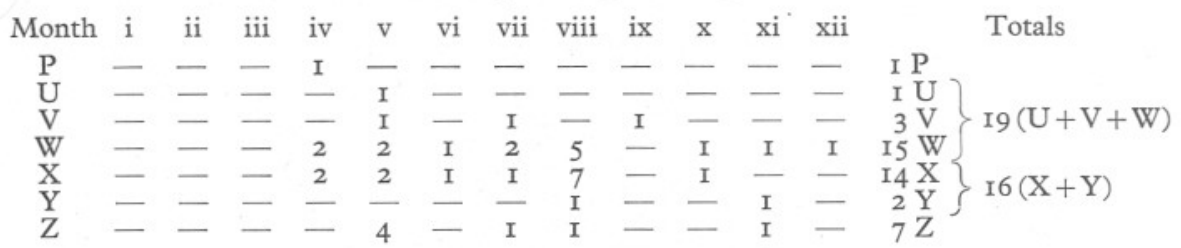

Symbols used to denote the substages found

$\mathrm{P}=$ 'Pennella' stage.

$\mathrm{U}=$ Very young form: torsion of body just complete, but genital segment not yet swollen. Pale red in colour.

$\mathrm{V}=$ Very young form: antlers showing first bifurcation and penetrating into the branchial vessels. Medium red in colour.

$\mathrm{W}=$ Young form: antlers penetrating as far as ventral aorta, but no external egg strings. Deeper red, especially in the abdomen.

$\mathrm{X}=$ Full grown form: external egg strings emerging but not ripe.

$\mathrm{Y}=$ Fully mature form: egg strings hatching or spent, and body very dark red in colour; abdomen almost black.

$\mathrm{Z}=$ Remains of dead antlers embedded in sublingual and vascular tissue.

\section{B. Distribution of Substages on Fish of different Size Groups}

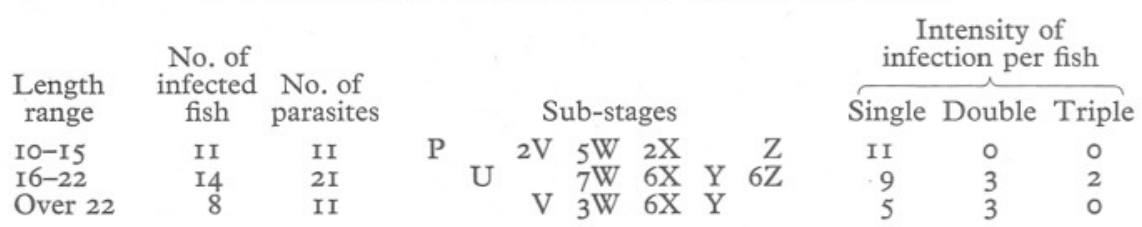

Notes. (I) The minimum length G. merlangus infected was II cm.; G. pollachius I2 cm. (2) Minimum length fish bearing dead parasite: G. merlangus $13.5 \mathrm{~cm}$. and G. pollachius I $5.5 \mathrm{~cm}$.

(3) Of the 8 multiple infections found, 7 were composed of parasites in two distinct substages. Proportion of multiple infections: $8 / 33(24 \cdot 3 \%)$.

(4) In all respects the parasites from the two host species were similar in their distribution, and for this reason the data are considered together.

shown in Table IV. The 'Pennella' stage was so called by Scott (I90I) to denote that stage of the fertilized female before the antlers grow out and just prior to torsion.

The occurrence of these various substages throughout the year is shown (Table IV A), and the last column shows the relative abundance of these stages 
over the period of observation. It is seen that the immature and mature stages are scattered in time, so that no definite infection or breeding period can be assigned to Lernaeocera.

Stekhoven (I936) and Stekhoven \& Punt (1937) have studied similar material from the cod from continental inshore waters at Helder, and they conclude that there is a simple annual cycle, that maximal infection of the intermediate host, the flounder, takes place in April and May, and that the mass infection of the cod is in midsummer. In their Table III (1937, p. 653) they give a summary of the details concerning $L$. branchialis from some dozen cod, all about $\mathrm{I}_{2} \frac{1}{2}$ years old. These data, however, do not seem to lend very convincing support to their conclusions, for the parasites were by no means of a similar age: about half of the number examined belonged to various immature stages ( $\mathrm{P}$ to $\mathrm{V}$ in our nomenclature), and of the rest, about a half were mature and the remainder consisted of dead remains. Apparently the collections were made only in the months of May and September, but the results show what is probably a typical cross-section of any population of Lernaeocera: for, in general, they agree with our findings on the distribution of the substages throughout the year. Our conclusions are, however, very different from these authors', for the data we have show conclusively that generations are being produced continuously all the year round.

Table V shows that the few flounders examined between December 1939 and December 1940 were all infected with the copepod developmental stages except those two fish below $10 \mathrm{~cm}$.

\section{Table V. The Infection of PleURonectes FlEsUS With the Developmental Stages and MaLes of LERNAEOCERA}

(December 1939 to December 1940, N. G. S.)

\begin{tabular}{|c|c|c|c|c|c|c|c|c|c|c|c|}
\hline Month & $\mathrm{ii}$ & ii & ii & iii & iv & iv & ix & ix & $\mathrm{xi}$ & xii & xii \\
\hline Length of fish & $12 \cdot 2$ & I3.4 & 13.5 & $9 \cdot 0$ & $10 \cdot 8$ & II. 5 & I $2 \cdot I$ & $17 \cdot 3$ & $9 \cdot 8$ & $22 \cdot 5$ & $12 \cdot 3$ \\
\hline No. of Lernaeocera & 3 & 8 & 7 & 0 & I6 & 7 & I & 2 & 0 & 20 & IO \\
\hline
\end{tabular}

On other fish: Cyclopterus lumpus, caught inshore on 3.iv. 40, had three mature males of a lernaeoceran on the gills, and Solea solea (also a fully grown fish), caught off Roscoff (France) on $3 . x .38$, had a single half-grown copepodid on the gills, which also belonged to this family of parasites (see Sproston, I94I).

All the flounders were caught in strictly inshore waters at Plymouth, and most of them from the seaward side of Laira Bridge in the Cattewater: $\mathrm{Mr}$ Spooner confirms our view that salinity and other conditions here are comparable with those near Saltash Bridge in the Tamar estuary. Records of hosts for the copepodid stages are sparse in the literature and they usually refer to the occurrence 'on flat fish such as the flounder' and similar vague terms. Claus and Metzger's original material came from the flounder as did Stekhoven's; it is curious that there are no records by the Plymouth workers at any time for these distinctive young stages. During the survey of the 
flounders in connexion with the Saltash Tuck-Net Fishery (P.H.T.H.) no special search was made, unfortunately, for gill copepods; indeed, there are no records extant for them from flounders taken in rivers or offshore, and the only localities mentioned are the inshore waters of Europe. It is also curious that so far no larval lernaeoceran has been recorded from the Western Hemisphere, though a species described by Wilson (19I7), closely allied to ours, is common on gadoids of the Atlantic seaboard. We think that it is safe to state that the normal intermediate host at Plymouth is Pleuronectes flesus, for though a thorough microscopical examination has been made of the gills of roo other flat fish caught at Plymouth between August 1939 and December 1940, no larval forms were found. The numbers of flat fish were distributed between nine species as follows: $P$. platessa $55, P$. cynoglossus $\mathrm{I}, . P$. microcephalus 2 , $P$. limanda 2I, Rhombus laevis 4, Arnoglossus laterna 3, Solea solea 9, S. variegata $\mathrm{I}$, and $S$. lutea 4 .

It is regrettable that no flounders were obtainable during the summer months at Plymouth; but that breeding of the parasite was taking place during this time is evidenced by the occurrence of mature adults shedding nauplii (see Table IV A, substage $\mathrm{x}$ ) - so that our evidence is complete for the continuous breeding of Lernaeocera.

By a careful examination of the facts at our disposal we can form some estimate of the length of the life cycle of this parasite. Eggs have been hatched in the laboratory in plunger jars containing sea water, and the pelagic copepodids were swimming actively on the second day. Some of these had attached themselves to the spent part of the egg strings, for want of other substratum, and had moulted, once at least, into the pupoid form which is described elsewhere (Sproston, I94I); this took place overnight and they lived for only a few hours afterwards. It is possible that these copepodid stages on the flounder are run through rapidly, for whenever seven or more were found together at least one was in the process of moulting. Stekhoven \& Punt (1937, p. 653) consider that as the pelagic fertilized female is seldom encountered, it must usually pass directly from the flounder to the cod when the latter migrates inshore. This, in general terms, is borne out by our observations on other gadoids, but the term 'directly' is misleading. It is improbable that so small and ill-equipped a crustacean could survive planktonic conditions in the open sea, and finally sink to the bottom and seek out a suitable gadoid; it is much more likely that the cycle is completed in the shallow inshore waters and in estuaries; but any direct transmission by actual contact is most unlikely. That these pelagic fertilized females can exist as free animals for short periods has been shown by Andrew Scott (I90I, p. 44), who collected them from filters placed over the outflow from the Peel flounder hatcheries: he says that he also caught males in this way, but their presence was accidental, since they normally die soon after copulation on the gills of the flounder. The ratio of males to females was $\mathrm{I}: 25$. Up to the beginning of the century these forms had only been taken by I.C. Thompson (I893, p. 212, pl. 26, fig. 7) in 
tow-nettings off Puffin Island off the coast of Anglesey; the succeeding stages-the 'Pennella' stages of Scott-have since been found on the gills of gadoids, and recently Stekhoven \& Punt (1937) have found an unbroken series (described in their Tables I and II). This series lacks, however, the extremely elongated form, showing the incipient antlers as small bulges on the cephalothorax, which was discovered by Thomas Scott in 1900 on the gills of a whiting in the Bay of Nigg, Aberdeen, and has never been found again (A. Scott, I90I, pl. IV, fig. 6). Regular tow-nettings have been taken outside Plymouth Sound throughout the year for a number of years, and Dr Lebour and Mr F.S. Russell, who have examined the plankton, inform us that they have never found a larval stage of Lernaeocera; this bears out our suggestion that a gadoid once out at sea does not become infected with L. branchialis.

For arriving at an approximation to the minimum length of the gadoid phase of the life cycle, the following rationale was employed. Since the youngest gadoid found infected was $I I .0 \mathrm{~cm}$. long and the youngest bearing a dead parasite was $13.5 \mathrm{~cm}$., then the whole phase may be completed while the fish is growing some $2.5 \mathrm{~cm}$. From the histograms this time may be estimated, very roughly, at 8 weeks.

Additional data in support of this are obtained from the age of epizootic organisms. In August I939 a third-year whiting was caught on the Shagstone Grounds bearing two Lernaeocera: one was immature (stage V) and the other, with half-spent egg strings, was covered with an epizootic hydroid. We are indebted to $\mathrm{Mr}$ W.J. Rees for examining this at the time and for his report on the specimen, which is as follows:

On the exposed gravid genital segment (the so-called body) of the L. branchialis there was a well developed colony of Clytia hemisphaericum (Gronovius) $=$ Clytia johnstoni (Alder, 1857). The hydrocauli were branched and numerous gonothecae were present containing medusa buds. The colony was normal in every respect and there was nothing to suggest that it was parasitic on the copepod. It was probably at least 6 weeks old and may have been two or three months old.

Many examples of a triple association between a fish, a parasitic copepod and a hydroid are known. Jungersen (I9II) cites several instances and also describes, a hydroid, Ichthycocodium sarcotretes occurring on Sarcotretes scopeli Jungersen, I9II (Lernaeoceridae). This hydroid he regards as semi-parasitic because the polyps possess no tentacles and no nematocysts.

A. Scott (1929, p. 108) gives the following information regarding epizootics: 'The Lernaeocera apparently live quite a long time. I have had specimens overgrown with zoophytes and young mussels $\mathrm{r} \cdot 3 \mathrm{~mm}$. long.' The length of mussel spat at the time of settlement appears from the records to be rather variable as it depends on local conditions; Matthews (I9I3, pp. 557-9) indicates that laboratory-bred spat settled when lengths were between I and $2 \mathrm{~mm}$., but that one young larva collected from the plankton had not settled though it was $4 \mathrm{~mm}$. long. Dr Lebour has kindly given us her opinion on the 
probable length of time during which Scott's specimens had been attached; this, she considers, may have taken place shortly before they were collected, and in any event they could not have settled more than a month previously.

Returning to Table IV, the relative frequency of the occurrence of the adult substages throughout the year may be taken as an approximate measure of the relative duration of those substages. The suggestion, in general terms, is that the frequency with which any phase is encountered in a regular and continuous sequence is proportional to the time occupied by that phase in the sequence. For instance, of the 36 living Lernaeocera found on the two species of gadoids, 20 were immature and I6 were mature, so that approximately five-ninths of the time is spent in the immature condition and fourninths of the time in the mature condition. Similarly, one-seventh of their time is taken up in penetrating from the outer to the inner vascular tissues, growing the antlers and completing the torsion of the body (substages $\mathrm{P}$ to $\mathrm{V}$ ), the rest of their time being divided about equally between continuing the growth of the genital segment, both in length and girth, and the final stage during which the egg strings are extruded and the ripe eggs shed. After this the animal remains alive for a short time (only two $\mathrm{Y}$ were found, so that it is fairly rare, i.e. probably a brief stage); death is followed by rupture and fragmentation of the projecting parts, leaving the antlers and some part of the 'neck' embedded in the tissues of the host.

Two direct observations on the living Lernaeocera are noted here as they have some bearing on the time factors of these substages. There was usually no difficulty in keeping the adult parasites alive in circulating sea water in the laboratory provided they were in no way injured during the dissection from the host. One W stage had been under observation for some hours when it started to extrude egg strings; after about $3 \mathrm{hr}$. approximately half the normal bulk of egg strings were extruded, but the eggs were pale and there was no sign of nauplii in the distal ones. At this time, unfortunately, these observations had to be concluded owing to an air-raid. Other egg-bearing females have been kept under observation for some days; in one the nauplii were hatching from the distal eggs as these became detached, over a period of 4 days' observation, and though at the end of this time the animal was sacrificed for another experiment, there was no marked diminution in the mass of the remaining egg strings. Though no measurements have been made to determine the rate of shedding of the eggs it seems that this is protracted over, perhaps, 2 or 3 weeks. Under natural conditions the eggs may be shed more rapidly owing to the projection of the end of the genital segment of the ripe female into the surrounding water, a little beyond the operculum of the fish.

Owing to this protracted shedding of ripe eggs the metanauplii from the first eggs liberated may well have passed through several, or even all, their stages on the flounder by the time the last sister egg has just hatched out. Nevertheless, it is unlikely that the same flounder is the recipient of the whoie 
gamut of larvae from one female L. branchialis, though superficially the facts suggest this: for in all the infected flounders examined bearing seven or more larvae, some of the latter were males and females in the fertilization stage and some were newly arrived copepodids which had not yet become attached by the rostral filament, but were merely hanging on to the gills by their chelate second antennae. This variety of stages probably represents infection from several parents; this is an acceptable view considering the extremely high infection rate of the flounders from the seaward end of estuaries.

From the above account it seems probable that L. branchialis, at least at Plymouth, has about four or five consecutive generations a year, and that these generations show an infinite degree of overlap.

Multiple Infections of Gadus merlangus and $\mathrm{G}$. pollachius with $\mathrm{L}$. branchialis

The records of multiple infections of fish caught in the sea near Plymouth are shown in Table IV B: and since seven out of eight of those recorded within the limits of inshore waters consisted of parasites of distinctly different ages, any possibility of immunity is precluded. This has already been demonstrated by the similar findings of Stekhoven \& Punt (I937, Table III). That the chances of reinfection increase with the age of the fish (provided that the latter remains inshore or in the estuary) is demonstrated by the absence of reinfection in fish less than $15 \mathrm{~cm}$. long, and its presence to the extent of $24.3 \%$ TABle VI. Distribution of LERNAEOCERA BRANCHIALIS ON
GADUS MERLANGUS AND G. POLLACHIUS

Intensity of Infection per Fish from the Tamar Estuary, 1936 and 1937 (P.H.T.H.)

\begin{tabular}{|c|c|c|c|c|c|c|c|}
\hline \multirow{3}{*}{$\begin{array}{l}\text { Length } \\
\text { range }\end{array}$} & \multirow{3}{*}{$\begin{array}{l}\text { Infected } \\
\text { fish }\end{array}$} & \multicolumn{6}{|c|}{ Multiple infections } \\
\hline & & \multirow[b]{2}{*}{ No. } & \multirow[b]{2}{*}{$\%$} & \multicolumn{4}{|c|}{ No. of parasites per fish } \\
\hline & & & & I & 2 & 3 & 4 \\
\hline \multicolumn{8}{|l|}{ G. merlangus: } \\
\hline Under $15 \mathrm{~cm}$. & I9 & 5 & 26 & I4 & 5 & 0 & o \\
\hline Over $15 \mathrm{~cm}$ & 58 & I4 & 24 & 44 & 7 & 6 & I \\
\hline Total & 77 & 19 & $24 \cdot 7$ & 58 & I2 & 6 & I \\
\hline \multicolumn{8}{|l|}{ G. pollachius: } \\
\hline Total fish & II & 3 & $27 \cdot 3$ & 8 & I & 2 & 0 \\
\hline Both species & 88 & 22 & 25 & 66 & I3 & 8 & I \\
\hline
\end{tabular}

in fish over $15 \mathrm{~cm}$. long from inshore waters. In Table VI similar results from the estuary are given as far as our records permit. The multiple infections are shown here also for both host species together for comparison with those from the sea. One fact which is difficult to explain is that in whiting from the Tamar there is no increase of multiple infection with age of the fish as shown above. The other outstanding result is the remarkable agreement in each fish and in each habitat of the proportion of multiple infections to the 
total number of infections (about a quarter). Considering the number of fish examined, this figure is perhaps rather high; and it is regrettable that larger numbers of fish were not examined from both habitats so that the results could have been treated statistically, to test the possibility of infection being a predisposing factor for reinfection.

\section{Clavella uncinata (O. F. Müller) (Fam. Lernaeopodidae) \\ Some Factors Influencing its Distribution on \\ Gadus merlangus and $\mathrm{G}$. pollachius}

The distribution of Clavella shows, in some respects, a marked contrast to that of Lernaeocera, particularly in relation to the inshore and offshore migrations of the hosts. Its occurrence month by month in the three habitats on Gadus merlangus and G. pollachius is shown in Tables I and II respectively. The incidence on fish of known length has been examined for G. merlangus in the estuary (P.H.T.H.) and for both species from the sea (N.G.S.), but as there is no very important correlation these details are not reproduced here. The seasonal occurrence is at first sight significant in the estuary, for it was found on G. merlangus only during the last third of the year; this, however, is more likely to be a length correlation, since a similar seasonal variation was not found inshore.

TABLE VII. INFECTION of GADUS MERLANGUS AND G. POLLACHIUS WITH CLAVELLA UNCINATA SUMMARIZED ACCORDING TO THE GROWTH OF THE FISH

\begin{tabular}{|c|c|c|c|c|c|c|c|}
\hline \multirow{6}{*}{$\begin{array}{l}\text { Length } \\
\text { range } \\
9 \cdot 5-15 \mathrm{~cm} \text {. } \\
\text { Over } 15 \mathrm{~cm} . \\
\text { Total }\end{array}$} & \multicolumn{3}{|c|}{ Gadus merlangus } & \multirow{3}{*}{\multicolumn{4}{|c|}{$\begin{array}{l}\text { Gadus pollachius } \\
\text { Of the I } 57 \text { fish examined only one was } \\
\text { infected with Clavella (in November } \\
\text { 1936): } 0.64 \%\end{array}$}} \\
\hline & \multirow{4}{*}{$\begin{array}{l}\text { No. } \\
\text { fish } \\
\text { examined } \\
253 \\
258\end{array}$} & \multicolumn{2}{|c|}{ With Clavella } & & & & \\
\hline & & \multirow{4}{*}{$\begin{array}{l}\text { No. } \\
25 \\
8 \\
33\end{array}$} & \multirow{4}{*}{$\begin{array}{l}\% \\
9 \cdot 9 \\
3 \cdot 1 \\
6 \cdot 45\end{array}$} & & & & \\
\hline & & & & & & & \\
\hline & & & & & & & \\
\hline & $5 \mathrm{II}$ & & & & & & \\
\hline \multicolumn{8}{|c|}{ B. From Inshore Waters, I939 and I940 (N.G.S.) } \\
\hline \multirow{2}{*}{\multicolumn{4}{|c|}{$\begin{array}{l}\text { Gadus merlangus } \\
\text { No. With Clavella }\end{array}$}} & \multicolumn{4}{|c|}{ Gadus pollachius } \\
\hline & & & & \multirow{5}{*}{ 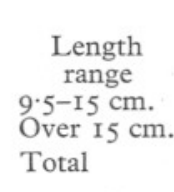 } & \multirow{2}{*}{$\begin{array}{l}\text { No. } \\
\text { fish } \\
\text { examined }\end{array}$} & \multicolumn{2}{|c|}{ With Clavella } \\
\hline \multirow{4}{*}{$\begin{array}{l}\text { Length } \\
\quad \text { range } \\
9.5-15 \mathrm{~cm} \text {. } \\
\text { Over } 15 \mathrm{~cm} . \\
\text { Total }\end{array}$} & $\begin{array}{c}\text { fish } \\
\text { examined }\end{array}$ & No. & & & & No. & $\%$ \\
\hline & 4 & 3 & & & 87 & & \\
\hline & 29 & 8 & 27 & & 25 & II & 44 \\
\hline & 33 & II & $33 \cdot 3$ & & II 2 & $3 \mathrm{I}$ & $27 \cdot 7$ \\
\hline \multicolumn{4}{|c|}{$\begin{array}{l}\quad \text { Gadus merlangus } \\
\text { Of the } 47 \text { fish examined, all of which } \\
\text { were over } 20 \mathrm{~cm} \text {., eight were infected: } \\
\text { I } \% \%\end{array}$} & \multicolumn{4}{|c|}{$\begin{array}{l}\text { Gadus pollachius } \\
\text { Of the four fish examined two were } \\
\text { infected (A.M.L. }=30.0 \mathrm{~cm} \text {.) }\end{array}$} \\
\hline
\end{tabular}

When the results are summarized according to the growth of the fish (Table VII), some interesting factors suggest themselves: first, the marked difference in the infection rates of estuarine and inshore fishes. The total infection rate 
of Lernaeocera branchialis on the two species of host in the estuary and inshore was 13.2 and $22.5 \%$ respectively, whereas for Clavella uncinata it was 5 and $3 \mathrm{I} \%$. That the increase in infection with Lernaeocera branchialis inshore is due to the 'lingering' effect of parasitized fish being intensified, has already been suggested. Parasitism with Clavella, however, does not seem to have any such repercussions on the migratory habits of the host, and the six-fold increase in infection of inshore fish as compared with those from the estuaries seems to be brought about by a different set of factors. The most probable is its lower tolerance to dilution of the external medium. Experiments described elsewhere (Panikkar \& Sproston, I94I) have shown that Lernaeocera branchialis, by virtue of a normal osmotic concentration below that of sea water, can tolerate dilution of the external medium at least down to $2 \cdot 24 \% \mathrm{NaCl}$, which is probably lower than that normally tolerated by the host. Unfortunately, no experiments on the osmotic behaviour of Clavella have been made, but casual observations have repeatedly shown that it dies quickly when very little tap water is added to the sea water in which it will live for some hours in the laboratory. Lernaeocera, on the other hand, has been kept alive under laboratory conditions (isolated from the host) for over a week on several occasions.

An important paper published recently (I939) by Poulsen, on the biology of Clavella uncinata, contains a great deal of interesting information; the distribution of this parasite on the cod in Danish waters was extensively investigated and it was found to be fairly common, especially in the Cattegat and in the Belt Sea, but infection decreased with salinity and Poulsen considers that of $16 \%$ oo to be lethal. He also remarks on the difficulty of determining the exact salinity level at which fish are found; from his maps (Figs. $6,7)$ it seems that the relatively highly infected fish of the Belt Sea area were caught in $10-20 \mathrm{~m}$. of water, or even beyond the $20 \mathrm{~m}$. line. Even if fish were confined to the bottom layers where salinity is highest, this is appreciably lower than the mean bottom salinity in the Tamar estuary. Poulsen quotes Jacobson's figures for the Belt Sea at $20 \mathrm{~m}$. as $20-26 \%$, but the bottom salinity of the Tamar estuary where other species of gadoids were found does not fall below $24 \%$ even in winter. It may be that a local race of $C$. uncinata has become adapted to the more brackish conditions of the Danish waters. It would be interesting to know the distribution of Lernaeocera spp. in the same region.

Poulsen found that no year-class 0 fish were infected, but that the highest infection occurred in the year-class i fish $(38 \%)$, thence falling steadily as the age advanced. The smallest cod found with Clavella was II.0 cm. long, and this Poulsen includes in year-class i. There is a possibility that the sudden increase in infection in the yearling cod may be correlated with their migratory habits: a relatively high minimum salinity being the limiting factor. Graham (I934) discusses the state of our knowledge of the migration of young codling and he considers that, while it is true that there is a winter visitation of these 
young fish into inshore waters, Meek's theory (I9I6) of a periodic (annual) in- and offshore migration is by no means proven. He thinks it more likely that there is a general scatter of the post-larval phase and, since they seem to like a rough bottom where crustacean food is abundant, any fish entering inshore waters may remain there provided that the bottom is suitable, in spite of other inclement factors; though Graham was careful to point out that the data in his possession were insufficient to make more than a working hypothesis. If the young codling are in inshore Danish waters, where the salinity is lower than elsewhere, then it is possible that the absence of Clavella on the year-class $\circ$ fish may thus be accounted for, and that they become infected after their first offshore migration.

Among the infected Gadus merlangus in the Tamar estuary there was one small fish $(8.8 \mathrm{~cm}$.) which was certainly in its first year; the smallest inshore infected fish measured $9.6 \mathrm{~cm}$. and as this was the only one infected below Io $\mathrm{cm} ., 9.5 \mathrm{~cm}$. was taken as the arbitrary minimum, and only fish above this length are considered in the following analyses. From Table VII it is seen that in the estuary the infection of G. merlangus dropped to a third of its intensity after the period of maximum growth, but on the other hand, inshore G. pollachius showed nearly double the infection after the period of maximum growth. We can offer only one explanation for this result; perhaps the decreasing salinity conditions met with by the growing fish in the river as the season advanced were such as would be unfavourable to the developing nauplii, so that few succeeding generations were forthcoming to reinfect the stock. However this may be, it seems that conditions in the Sound were altogether more favourable to the parasite, for here the degree of infection is of a similar order to that found by Poulsen in Danish waters for the allied species of host of the same age.

The susceptibility of the various species of gadoids to infection with Clavella is similar to that with Lernaeocera, except that we have not found the former on Gadus luscus; one specimen of each parasite was taken from G. minutus from the sea but none from the river. In spite of the unequal distribution of Clavella on the gadoids of the estuary (Table VII A), the total infections from our combined records are not very dissimilar:

$\begin{array}{lccc}\text { Species } & \begin{array}{c}\text { Total no. of } \\ \text { fish examined }\end{array} & \begin{array}{c}\text { Total no. of } \\ \text { fish infected }\end{array} & \begin{array}{c}\% \text { infection } \\ \text { G. merlangus }\end{array} \\ \text { G. pollachius } & 273 & 52 & 8 \cdot 8 \\ \text { Both species } & 864 & 34 & 12 \cdot 5 \\ & & 86 & 10 \cdot 0\end{array}$

The Duration and Distribution of the Later Developmental

Phases of Clavella uncinata

Unlike Lernaeocera, Clavella has only a single host in its life cycle, so that the hazards of the free living stages are enormously reduced as compared with those of the former type of parasite. Perhaps as a direct consequence of this 
Clavella produces fewer eggs. Gurney (1934) has given the first and only account of the complete developmental cycle of this copepod. He had considerable difficulty in rearing copepodids from eggs under laboratory conditions at Plymouth, but later he was able to collect a series of intermediate forms from gills of local pollack.

Some I50 gadoids have been examined throughout the year by one of us (N.G.S.), but the pupa-like developmental stages described by Gurney have not yet been found. The various adult substages have, however, been found in several months of the year. As Gurney did not suggest any grouping of these substages, we have tentatively divided them into three as indicated in Table VIII; in section A of this table their distribution is shown throughout the year.

\section{Table VIII. Substages of Adult ClaVElla UnCINATA on GadUS MERLANGUS AND G. POLLACHIUS}

From Inshore and Offshore Waters near Plymouth, I939 and I940 (N. G. S.)

A. Distribution of Substages Throughout the Year

$\begin{array}{cccccccccccccc}\text { Month } & \text { i } & \text { ii } & \text { iii } & \text { iv } & \text { v } & \text { vi } & \text { vii } & \text { viii } & \text { ix } & x & \text { xi } & \text { xii } & \text { Total } \\ \text { X } & \text { I } & - & - & - & - & - & 2 & \text { I3 } & 3 & - & 8 & - & 27 \text { X } \\ \text { Y } & - & 3 & - & \text { I } & \text { I } & - & 2 & 8 & 2 & \text { I } & \text { II } & - & 29 \mathrm{Y} \\ \text { Z } & 2 & - & - & 2 & 4 & 2 & 2 & \text { I } 8 & 3 & \text { I3 } & \text { I3 } & \text { I } & 60 \mathrm{Z}\end{array}$

Symbols used to denote the substages of the 'adult' parasite

$\mathrm{X}=$ all very young forms in which the genital segment has not swollen and is about one-third of the body in size.

$\mathrm{Y}=$ young immature forms in which the genital segment has swollen but in which the egg strings have not emerged.

$\mathrm{Z}=$ mature forms with external egg strings, including those with spent egg strings.

\begin{tabular}{|c|c|c|c|c|c|c|c|c|}
\hline \multirow{4}{*}{$\begin{array}{l}\text { Length } \\
\text { range } \\
9 \cdot 5-15 \\
16-20\end{array}$} & \multirow{3}{*}{$\begin{array}{l}\text { In- } \\
\text { fected } \\
\text { fish } \\
22\end{array}$} & \multirow{2}{*}{$\begin{array}{l}\text { No. of } \\
\text { para- } \\
\text { sites }\end{array}$} & & & & \multicolumn{3}{|c|}{ Multiple infections } \\
\hline & & & \multicolumn{3}{|c|}{ Substages } & No. & $\%$ & No. fish (No. parasites) \\
\hline & & 29 & ro $\mathrm{X}$ & II $Y$ & $8 \mathrm{Z}$ & 4 & I8 & I8 (I), 3(2), I (3) \\
\hline & II & 26 & $6 \mathrm{X}$ & $7 \mathrm{Y}$ & I3 $\mathrm{Z}$ & 4 & 36 & $\begin{array}{l}7(\mathrm{I}), \text { I (2), I (3), I (5), } \\
\text { I (9) }\end{array}$ \\
\hline Over 20 & I5 & 62 & I I $\mathrm{X}$ & II $\mathrm{Y}$ & $40 \mathrm{Z}$ & 8 & 53 & $\begin{array}{l}8(\mathrm{I}), 2(2), \mathrm{I}(3), \mathrm{I}(7), \\
\text { I (9), I (10), 2(II) }\end{array}$ \\
\hline
\end{tabular}

Notes. (I) Minimum length of G. merlangus infected II $0 \mathrm{~cm}$; G. pollachius $9.6 \mathrm{~cm}$.

(2) Minimum length of $G$. merlangus with $Z$ stage II. $5 \mathrm{~cm}$; $G$. pollachius $14.0 \mathrm{~cm}$. No dead and disintegrating parasites were found.

(3) Among the multiple infections in the three groups the following proportions of fish had dissimilar stages occurring together: smallest $\frac{1}{4}$, medium $\frac{3}{4}$ and largest $\frac{4}{8}$.

(4) As with Lernaeocera the two hosts showed similar distribution of parasites in all respects.

There is a slight indication of two main breeding seasons, though the number of specimens is insufficient to warrant a definite conclusion. The youngest adult substage occurs throughout the summer and autumn but is absent in the spring, but the maturing forms $(\mathrm{Y})$ were found all the year round, though the mature forms $(Z)$ were always more abundant, with a concentration in summer and autumn of about four times the average monthly distribution. It is not likely that the few Y group individuals recorded in the spring were remnants of the previous year's brood, for we have every reason 
(see below) to think that these substages are passed through fairly quickly; it is more probable that they represent an early brood of the same year: the $\mathrm{X}$ substages corresponding to these were not found by us. Using the same approximation as was employed above for Lernaeocera in order to form a rough estimate of the incidence in time of these substages, it will be seen that in the last column of Table VIII A the numbers of immature forms (X and Y) together are about equal to the number of mature $(\mathrm{Z})$ forms, also that the numbers of $\mathrm{X}$ and $\mathrm{Y}$ are nearly equal. Thus, it is probable that the time spent in completing the $\mathrm{X}$ and $\mathrm{Y}$ phases is nearly the same, and that each is about half that of the mature phase $Z$. The smallest whiting and pollack infected in inshore waters, from which these data were mostly collected, were respectively II and $9.6 \mathrm{~cm}$. in length, and the smallest infected with a mature egg-bearing Clavella were II. 5 and $14.0 \mathrm{~cm}$. Accordingly, at least in the whiting, the $\mathrm{X}$ to $\mathrm{Z}$ substages are passed through within a few weeks, perhaps about a month at a rough approximation. From Table VIII A it thus seems that reproduction takes place throughout the year as it apparently does also in Lernaeocera.

In Table VIII $B$ it is seen that the number of mature egg-bearing females increases with the length group of the fish, i.e. it is in accordance with the probability of infection increasing with the time of exposure of the host under favourable conditions for infection. (It was assumed that estuarine conditions were not so favourable, hence the decreasing infection rate with age of fish-vide Table VII A.) Further, the rapid increase in the numbers of $Z$ forms may be due to the longer persistence of this stage, causing, in effect, a 'piling up' of this final stage on the older fish.

\section{Multiple Infections}

The increasing percentage of multiple infections with the length group of the fish from the sea (Table VIII B) clearly demonstrates that there is no immunity to superinfection developed by the fish. In half of the multiple infections the parasites were of markedly dissimilar ages (see note 3, Table VIII). In the third-year whiting caught offshore it was common to find a large number of parasites of graded ages, and in some of them there were no

\section{Table IX. Distribution of CLAVELla unCinata on Gadus MERLANGUS AND G. POLLACHIUS \\ Intensity of Infection per Fish from the Tamar Estuary, 1936 and 1937 (P.H.T.H.)}

All of the 33 fish infected were less than $15 \mathrm{~cm}$. long, the smallest infected fish was $8.8 \mathrm{~cm}$.

No. of parasites per fish: $\begin{array}{lllll}\text { I } & 2 & 3 & 4\end{array}$

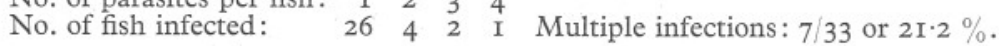

mature $\mathrm{Z}$ forms; so that these successive stages must represent superinfection from other fish. It is quite probable that autoinfection occurs on one host, for spent females have also been found in company with very young $\mathrm{X}$ forms.

The state of maturity of the parasites found on the gadoids from the Tamar 
estuary was not determined, but data were collected regarding multiple infection and are given in Table IX. Since all the infected fish from this habitat were of the first length group dealt with from the sea, they are comparable and, indeed, they do show a similar rate of superinfection (2I \% as compared with $18 \%$ ).

\section{Direct Effects on the Host resulting from Infection by Clavella}

As with Lernaeocera, the values for the condition factor, $K$, of the hosts have been determined for fish infected with Clavella, but as they show no correlation whatever with infection, they are not reproduced here. Similarly, there is no consistent variation in the arithmetic mean lengths of monthly groups of fish infected and not infected with Clavella (see Tables I, II); so as far as our data go, it may be said that Clavella has no appreciable effect on the host.

Clavella is much smaller than Lernaeocera and it seldom occurs in very large numbers; moreover, it is probably mainly a mucus feeder, though it may also feed on detritus and on gill tissue. In the pollack its habitat is distinctive, and in all specimens except one the parasites were found on the tips of the gill filaments, and usually on the first gill of each side (though sometimes also on the second gill), and situated towards one or the other end of the gill rather than in the middle region of the gill arch. When full-grown parasites were found on the pollack the adjacent four or five gill filaments, both on the gill to which it was attached and on the next gill, were shorter and appeared to have been browsed down to the extent of one-fifth or one-sixth of the length of the normal filaments. These browsed gill filaments did not, however, show a marked anaemia, though they were usually adherent, suggesting a hypersecretion of mucus resulting from the irritation and feeding of the parasites. Dawes (I940) has made a much-needed contribution to our knowledge regarding the histological effect of trematode gill parasites on their hosts, and though no such detailed investigations have been made in the present study, it seems quite possible that the effects are comparable. Poulsen (I939, p. 24I, Fig. viii) gives a figure of an eroded fin of a cod caused by the browsing of Clavella: this shows a whitish edge which is thickened on the eroded margin. $\mathrm{He}$ considers that the effects on the gills would cause a more vital injury, and that in both instances the mechanical presence of the parasite would affect the movements or reduce the efficiency of the respiratory current in the branchial cavity. Hence, he suggests that Clavella may have a distinct detrimental influence on the growing stock, since at least in Danish waters the incidence of infection is fairly high. He has also determined the condition factors for infected and uninfected fish, but his results do not show any significant correlation. His explanation is that those fish taken to be uninfected have probably been infected in the recent past, and their lowered condition factor would produce a spuriously low mean value among the 'uninfected' fish.

The Clavella found on the whiting were never attached to the gill filaments: 
on the smaller fish they were invariably found attached to the gill rakers on the first gill and more rarely on those of the second: they are actually more common on the small spinose bosses on the inner margin of the gill arch, though they are also found quite frequently on the long rakers on the outer margin of the first gill. In the older whiting, however, it was not unusual to find Clavella also attached to the roof and sides of the buccal cavity and sometimes on the tongue, but they were rarely found on the inner face of the operculum and never (as they are on the cod) on the outer surface of the body. Though there is no specific difference between the Clavella infecting the two common gadoids at Plymouth (Gurney, 1934) there is a distinct influence exerted in some way by each kind of host which determines the characteristic habitat taken up by the infective copepodid of the Clavella.

It may be added that the whiting may be expected to suffer much less from the presence of this parasite than the other gadoids, for the situation of the parasite is usually well removed from soft tissues and, on this host, it must be largely a detritus feeder.

\section{The Genus Lepeophtheirus (Fam. Caligidae)}

Like all other caligids, the species of Lepeophtheirus have a single host in their life cycle; in this they resemble Clavella, but unlike the latter they are not permanently attached to the host. As a group they are among some of the least modified of parasitic copepods. They are primarily marine, and owing to their thin cuticle, which may be subservient alike to excretion and gaseous exchange, they are unable to withstand marked or rapid changes in salinity of the external medium. Their sensitivity to reduced salinity when the host enters more or less brackish waters is illustrated by the distribution of L. pollachii and L. pectoralis at Plymouth.

Gurney (1933, p. 334) quotes Hutton's observations on L. salmonis. Hutton has found the parasite 85 miles from the sea and has shown that it can withstand fluviatile conditions for two weeks or more; but this is exceptional, and the fact that the egg strings very soon break away from the females denotes that conditions are certainly not suitable for breeding. The females are said to be less viable than the males. Gurney endorses the popular belief that their presence on a fish is strong evidence that it is freshly run from the sea. The present records do not include this species.

L. pollachii may have been overlooked in the samples taken from the Tamar estuary as no special search was made for it; but it was occasionally taken during 1939 and 1940 from the seaward end of the estuaries and from Plymouth Sound, as well as from offshore habitats, so that it is capable of withstanding a slight dilution of the external medium. Details of its occurrence are given in Table II C.

Perhaps the chief factor in limiting its distribution to the larger fish is its rigorous preference for a peculiar habitat: it is invariably found attached to 
the under-side of the tongue of pollack, though sometimes it occurs in other positions in the sublingual space after the death of the host. It has never been found on the operculum or outer surface of the body, and never on any other gadoid. Chalimus stages have not been found. Its absence from the smaller fish is therefore explained by the habitat being too small to accommodate it. There is no obvious seasonal variation in numbers, but our collection was too small to study this species from the point of view of breeding phases.

L. pectoralis is usually considered a very abundant parasite on pleuronectids, and unlike the foregoing species shows no marked preference for a particular species of host. Its habitat is not quite so constant as that species, though it is usually found in the neighbourhood of either of the pectoral fins. That it is even more sensitive to dilution of the external medium is shown by its absence at all times from Pleuronectes flesus and P. platessa caught at the seaward end of the estuaries at Plymouth, although it was found occasionally on these fish caught in the Sound. Over 2500 flounders and a considerable number of plaice from the Tamar estuary were examined by one of us (P.H.T.H.) during 1936 and 1937, but not a single specimen of Lepeophtheirus pectoralis was found, though a careful search was made for them. A single $(20 \mathrm{~cm}$. long) specimen of Pleuronectes flesus caught in the Sound harboured this species. The incidence of infection of P. platessa in the Sound, as estimated from casual observations, seems to be lower than that usually met with in offshore waters. The low percentage of infection in our records is probably due to the majority of our fish being caught at the seaward end of the estuaries; these fish were young ( $0-i$ year class).

TABLE X. INCIDENCE OF LEPEOPHTHEIRUS PECTORALIS ON PLEURONECTES PLATESSA: 'INSHORE'

$\begin{array}{lcccccc}\text { Year class } & \circ & \text { i } & \text { ii } & \text { iii } & \text { iv } & \text { Total } \\ \text { Length range (cm.) } & \text { Up to } 9 & 9-\text { Ir } 8 & \text { I8-24 } & 24-30 & \text { Over } 30 & \\ \text { No. of fish examined } & 2 & 26 & \text { II } & 6 & 9 & 54 \\ \text { Length of infected fish } & - & \text { I2.5 } & - & 24 \cdot 0 & 34 \cdot 0,38 \cdot 0 & 4 \text { fish } \\ \text { Month of capture } & - & \text { Jan. } & - & \text { Aug. } & \text { Oct. and Feb. } 7 \cdot 4 \%\end{array}$

\section{Notes ON THE DisTRIBUTION OF LERNAEENICUS SPP. ON THE SPRAT}

This genus of parasites belongs to the same family as Lernaeocera and may have similar powers of toleration to brackish water. No sprats have been examined from the sea during the present investigations; but the following records, made during the study of the Saltash tuck-net fishery of the Tamar estuary (Hartley, 1940, p. 42), are included here for comparison with the related Lernaeocera on gadoids from the same habitat. As was found with Lernaeocera, the several species of Lernaeenicus have characteristic habitats which are adhered to rigorously: Lernaeenicus sprattae is always found on the eye and L. encrasicola is embedded into the body musculature, the head 
sometimes reaching through to the coelom. The distribution of infected specimens of Clupea sprattus with the two species of Lernaeenicus is summarized in Table XI. The incidence of infection is rather low, and about a third of the infected sprats probably belonged to the stock of the previous year. This may be another instance of the lingering inshore of fish infected with parasites of this family. It is also interesting to note that the $8.0 \mathrm{~cm}$. fish caught in September 1936 had a triple infection of Lernaeenicus sprattae on one eye. In this host, therefore, as in gadoids, there is no immunity developed.

\section{TABle XI. InfeCtion of CLUPEA SPRATTUS WITH LERNAEENICUS IN THE TAMAR Estuary, I936 and I937 (P. H. T. H.)}

\begin{tabular}{|c|c|c|c|c|c|}
\hline \multirow[b]{2}{*}{ Year } & \multirow{2}{*}{$\begin{array}{l}\text { No. of } \\
\text { fish } \\
\text { examined }\end{array}$} & \multicolumn{2}{|c|}{ With L. sprattae } & \multicolumn{2}{|c|}{ With L. encrasicola } \\
\hline & & No. & $\%$ & No. & $\%$ \\
\hline I936 & 477 & 5 & $I \cdot I 2$ & I & 0.21 \\
\hline I937 & 899 & 4 & 0.445 & 2 & 0.22 \\
\hline Total & I 376 & 9 & 0.655 & 3 & 0.22 \\
\hline
\end{tabular}

Lengths of fish infected with Lernaeenicus

$\begin{array}{cccc}\text { Date } & \begin{array}{c}\text { A.M.L. for } \\ \text { sample }\end{array} & \begin{array}{c}\text { With } \\ \text { L. sprattae }\end{array} & \begin{array}{c}\text { With } \\ \text { L. encrasicola }\end{array} \\ \text { I936 } & 8.78 & \text { I0.1 } & 8.4 \\ \text { 23 May } & 4.88 & 5.4 & - \\ \text { I9 Aug. } & 4.82 & 6.8 ; 8.9 ; 8.0 & - \\ \text { I8 Sept. } & 7.25 & 7.5 & - \\ \text { 2 Oct. } & 5.21 & - & 6.6 \\ \text { I937 } & 4.92 & 5.1 & - \\ \text { 21 Jan. } & 5.33 & 5.8 & 5.5 \\ \text { I Feb. } & 6.02 & 5.7 & - \\ \text { April } & 3.63 & 3.6 & - \\ \text { 8 May } & & & \end{array}$

Neither L. sprattae nor $L$. encrasicola is very common round our coasts. ${ }^{1}$ Scott \& Scott (1913, pp. I56-9) mention a catch of 600 sprats from the shrimping grounds off Blackpool which yielded a $2.3 \%$ infection with L. sprattae. Leigh-Sharpe (1935, pp. 270-5, Figs. I-7) redescribes and figures these two parasites from material obtained from the Tamar estuary in the spring of 1934; he obtained 29 from 960 fish $(2 \cdot 9 \%)$, and he states that Dr Gurney examined a catch of over a thousand fish from the same locality at about the same time and obtained a similar percentage of infection. He does not record any multiple infections, though among Scott's material one fish had three on one eye.

\footnotetext{
${ }^{1} \mathrm{Mr}$ Ford recalls examining large catches of sprats at Plymouth among which some specimens had black holes in the eye, which he took to indicate the sites of previous infection with this parasite. Unfortunately these specimens were destroyed by enemy action, but the possibility remains that the real rate of infection of sprats is higher than the apparent rate given above.
} 
L. encrasicola is even less common. A. Scott (1907, p. 94) examined some hundreds of sprats caught off Blackpool in February 1906 and only found a single infected fish, and Leigh-Sharpe found only one among the 960 fish from the Tamar; the 1936 and 1937 catches from the same locality yielded a slightly higher percentage $(0.2 \%)$. We have no data as to the condition of the infected sprats, but observers state that $L$. sprattae causes blindness, which would indirectly lead to malnutrition and possible death; both species would cause a certain amount of debility through loss of tissue fluids on which they feed. These combined effects may explain the rarity of these two parasites.

\section{SUMMARY AND CONCLUSIONS}

The migratory habits of Gadus merlangus and G. pollachius are examined in relation to the variations in the rate of infection of these fish with Lernaeocera branchialis. A sudden increase in infection in estuarine and inshore waters is found to coincide with the offshore migration of the main stock. The infected fish apparently linger behind and may live for some time in the old habitats after the arrival of the next recruitment. The offshore migrants are seldom infected, and it is probable that infection does not take place in water deeper than about 5 fathoms.

The possible immediate causes of this 'lingering' phenomenon are examined, and two suggestions are made as to the nature of the physiological upset brought about by the presence of $L$. branchialis on these gadoids. Other factors influencing the distribution of the parasite are discussed.

The relative susceptibility of the different species of gadoids to infection with species of Lernaeocera is examined as far as the data allow.

The duration and distribution of the developmental phases on the intermediate pleuronectid and final gadoid hosts are estimated: the former being probably not more than two weeks, and the latter about six to eight weeks. Corroborative evidence for the length of the gadoid phase is obtained from certain epizootic organisms. The production of a vast number of eggs and their protracted shedding result in a scattered series of larval forms at all times of the year on the gills of flounders caught at the seaward end of the estuaries. There is likewise a scattered series of adult substages on gadoids. The numerical abundance of each phase is taken as being proportional to the length of time spent in each phase. There may be as many as five or six consecutive generations a year, but these generations show an infinite degree of overlap. The infection of the o year-class fish after their few weeks' sojourn in inshore and estuarine waters is correlated with the large numbers of larval forms found on flounders in this neighbourhood.

The lingering of parasitized gadoids, in effect, ensures the reinfection of the flounders: the ripe eggs from the female Lernaeocera on the gadoid are thus shed in shallow water where the conditions are optimum for the early development and for the minute free-swimming copepodids and their sub- 
sequent infection of the flounders on the gills of which they begin their metamorphosis. The coherence of these facts, and the rarity of infected gadoids in offshore habitats, suggest that $L$. branchialis is, par excellence, an inshore parasite. On the other hand, the relatively frequent occurrence of Gadus luscus infected with Lernaeocera lusci in offshore waters suggests that infection takes place there and that the intermediate host is a pleuronectid more adapted to deeper waters than Pleuronectes flesus. That this intermediate host can also live inshore is evidenced by the occurrence of occasional infected Gadus luscus among the young stock in the estuary during 1936-7.

Multiple infection with Lernaeocera of different ages, both on the flounder and on the gadoids, indicates that these fish do not develop an immunity to reinfection, and it may even be possible that infection and the consequent prolonging of inshore and estuarine life may favour reinfection. The distribution of the adult substages on Gadus merlangus and on G. pollachius is very similar in all respects.

The distribution of Clavella uncinata has been similarly studied on the two common gadoids from estuarine, inshore and offshore waters near Plymouth. Clavella, unlike Lernaeocera, is confined to a single host throughout its life cycle; it is therefore not subject to the same restrictions regarding breeding habits as the latter parasite, and successful egg production can take place at any time during the life of the host: it is independent of the migratory habits in this respect, though other limiting factors appear to be operative. As with Lernaeocera, infection is first recorded in the o year-class fish a few weeks after their inshore migration. In strictly inshore waters (Plymouth Sound) the rate of infection continues to increase with the age of the whiting and pollack, but in estuarine waters nearby the infection is at first moderate but later (after the period of maximum growth of the fish) tends to fall off: this may be an expression of inclement conditions for the infective stages, such as the reduced salinity of this habitat during the autumn and winter. The effect of reduced salinity on Clavella parasitizing the cod in Danish waters is also discussed. Clavella appears to be about equally common on the cod, whiting and pollack, but it is rare on Gadus minutus and it has not been found by us on $G$. luscus. The duration and distribution of the later developmental substages are estimated in the same way as for Lernaeocera, and it is concluded that all the adult substages are completed in a few weeks, and that the complete cycle is perhaps not longer than two months. Reproduction takes place throughout the year, though since conditions are more favourable at certain times the main recruitment to the Clavella stock takes place in the autumn in the sea near Plymouth. Multiple infections were also common with this parasite so that it induces no immunity in its host.

The direct effect on the host is discussed; as with Lernaeocera, there is no discernible difference in the condition factors of infected and uninfected fish. The difference in the habitat and food of Clavella on three species of gadoids is indicated. 
The species of Lepeophtheirus, like other caligids, are similar in body form and organization to the first stages of Clavella and Lernaeocera, and owing to their minute size and probable lack of osmoregulatory powers are unable to withstand salinity changes of any magnitude in the external medium as, for instance, when the host migrates into brackish waters. L. salmonis is more resistent than most caligids. L. pollachii has not been found in fish from estuarine waters and only occasionally in those caught inshore, but it is fairly common in fish caught out at sea. Its occurrence is primarily limited, however, by mechanical factors, i.e. the size of the sublingual space of the pollack, which is its invariable habitat. L. pectoralis is apparently most highly sensitive to reduced salinity, for it is strictly marine in occurrence: though quite adequate samples of Pleuronectes flesus were examined from estuaries no infected fish were found.

Data on the distribution of Lernaeenicus sprattae and L. encrasicola from Clupea sprattus in the estuary are included for comparison with Lernaeocera; though this is a consistently rare parasite, the records show that older infected fish tend to linger with the newly recruited estuarine stock of the following season. The effect on the host is discussed.

\section{ACKNOWLEDGEMENTS}

We wish to express our indebtedness to the Director and Staff of the Marine Biological Association's Laboratory for all the facilities offered under the present difficult circumstances, and for their individual help so generously given at all times. One of us (N.G.S.) wishes to thank the University of London for the permission to occupy the University table at Plymouth for two years, and for the award of the Post-Graduate Research Studentship (I939-4I) which has made these investigations possible.

\section{REFERENCES}

Dawes, B., I940. Hexacotyle extensicauda n.sp., a monogenetic trematode from the gills of the tunny (Thunnus thynnus L.). Parasitology, Vol. xxxII, pp. 27I-86.

Ford, E., I93I. In the Plymouth Marine Fauna, 2nd ed., p. 320.

Graham, M., I934. Report on the North Sea cod. Fish. Invest., Ser. II, Vol. XIII, no. 4, London. Section 5: The life cycle of the cod in the North Sea, pp. 68-75.

Gurney, R., 1933. British Fresh-Water Copepoda, Vol. III. London: Ray Society.

- 1934. The development of certain parasitic copepoda of the families Caligidae and Clavellidae. Proc. Zool. Soc. Lond., pp. I77-217.

Hartley, P. H. T., I940. The Saltash tuck-net fishery and the ecology of some estuarine fishes. Fourn. Mar. Biol. Assoc., Vol. xxiv, pp. I-68.

Hesse, E., I870. Description d'une nouvelle espèce de Crustacé parasite de l'ordre des Lernéidiens de la famille des Lernéocériens, et du genre Lernée, Lernée du Gade-petit, Lernaea gadi minuti (nobis). Ann. Sci. Nat., Sér. 5, Zool., Vol. xIII, pp. I-30. 
Hesse, E., I89I. Description d'une nouvelle Lernée branchiale du Chaboisseau de Mer à longues épines (Cottus bubalis, nobis). Ann. Sci. Nat., Sér. 7, Zool., Vol. xI, pp. 187-95. (As quoted by Wilson, C. B., I917.)

JUNGERSEN, H. F. E., I9II. On a new gymnoblastic hydroid (Ichthyocodium sarcotretis) epizoic on a new parasitic copepod, Sarcotretes scopeli, infesting Scopelus glacialis Rhdt. Vidensk. Medd. fra Dansk. naturh. Foren., Bd. LXIv, pp. I-33.

KEYS, A. B., I933. The mechanism of adaptation in the common eel and the general problem of osmotic regulation in fishes. Proc. Roy. Soc. B, Vol. cxil, pp. 184-99.

Leigh-Sharpe, W. H., I935. Two copepods (Lernaeenicus) parasitic on Clupea. Parasitology, Vol. xxvII, pp. 270-5.

Matthews, A., I9r3. Notes on the development of Mytilus edulis and Alcyonium digitatum in the Plymouth laboratory. Fourn. Mar. Biol. Assoc., Vol. Ix, pp. $557-60$.

MeEk, A., I9I6. The Migrations of Fish. London.

MilNe, A., I938. The ecology of the Tamar Estuary. III. Salinity and temperature conditions in the Lower Estuary. Fourn. Mar. Biol. Assoc., Vol. xxII, pp. 529-42.

Panikkar, N. K. \& Sproston, N. G., I94I. Osmotic relations of some metazoan parasites. Parasitology, Vol. xxxIII, pp. 214-23.

PoulsEN, E. K., I939. Investigations upon the parasitic copepod Clavella uncinata (O. F. Müller) in Danish Waters. Vidensk. Medd. fra Dansk. naturh. Foren., Vol. cII, pp. 223-44.

Scotr, A., I90I. Lepeophtheirus and Lernaea. L.M.B.C. Memoirs, Vol. vi. 1907. Report for 1906: Lancashire Sea Fish. Lab., no. I5, p. 9.

I929. The copepod parasites of Irish sea fishes: Report for I928. Lancashire Sea Fish. Lab., pp. 8I-I I9.

Scott, T., I909. Some notes on fish parasites. In 26th Ann. Rep. Fish. Bd. Scotland, Part 3, pp. 73-92.

Scotr, T. \& Scotr, A., I913. The British parasitic Copepoda, Vol. I. London: Ray Society.

SMITH, H. W., I930. The absorption and excretion of water and salts by marine teleosts. Amer. Fourn. Physiol., Baltimore, Vol. xcIII, pp. 480-505.

I932. Water regulation and its evolution in the fishes. Quart. Rev. Biol. Baltimore, Vol. viI, pp. I-26.

Sproston, N. G., I94I. The developmental stages of Lernaeocera branchialis (L.) (unpublished).

Sproston, N. G. \& Hartley, P. H. T., I94I. Observations on the bionomics and physiology of Trebius caudatus and Lernaeocera branchialis (Copepoda). Fourn. Mar. Biol. Assoc., Vol. xxv, pp. 393-4I7.

STEKHOVEn jr., J. H. SchuURMANS, I936. Beobachtungen zur Morphologie und Physiologie der Lernaeocera branchialis L. und der Lernaeocera lusci BassettSmith (Crustacea parasitica). Z. Parasitenk., Bd. viII, Heft 6, pp. 659-96.

Stekhoven jr., J. H. SchuURmans \& Punt, A., I937. Weitere Beiträge zur Morphologie und Physiologie der Lernaeocera branchialis L. Z. Parasitenk., Bd. IX, Heft 5, pp. 648-68.

Thompson, I. C., I893. Revised report on the Copepoda of Liverpool Bay. Proc. Liverpool Biol. Soc., Vol. vII, pp. I75-230.

VANDEN BERGHE, L., I933. Observations sur le sang et le peristaltisme alternatif de l'intestine chez les Lernées. Acad. Roy. Belg. Cl. d. sci., Sér. 5, Vol. xIx, pp. $82 \mathrm{I}-36$.

WILsON, C. B., I9I7. North American parasitic Copepods belonging to the Lernaeidae with a revision of the entire family. Proc. U.S. Nat. Mus., Vol. LIII, no. 2194, pp. I-I5O. 